\title{
Qarakhanid Allies and China
}

The chapter is structured around Chinese records on the Qarakhanid allies in the Turko-Islamic world. Initially, I was looking for accounts in Chinese sources of the Khitan mission sent to the Ghaznavid court that was only depicted by Central Asian medieval historians. I found it strange that this important delegation had not been recorded in any Chinese written document. I could not find references related to the Khitan mission to Ghazna but I discovered a "Persian" country in the Song shi entry on India that sent an envoy to Northern Song China.

Moreover, I found solid discussions in Chinese scholarship on several missions recorded in Song sources that could refer to the Saljuq embassies. I discuss different theories on the origin of these missions and introduce new data and hypotheses that may prove "the Saljuq version." However, it should be noted that the records discussed in this part relate definitively to India, Asia Minor, and the Islamic world, which has languished in obscurity outside of Chinese scholarship. These embassies are also valuable when discussing the Qarakhanids' role as middlemen between China and their neighbors in the west.

In particular, Chinese records on the Khwarazmshahs connected with the Mongol conquest are well known but paradoxically are rarely consulted. There are no sources in either China or Central Asia that would directly prove contact between Song China and the Khwarazmshah Empire. However, descriptions of the Khwarazmshahs and their territories left by travelers and envoys who visited the Genghis Khan court during his conquest of Central Asia provide the general image of the region in China. The Khwarazmshahs were known as "Uyghurs." This may explain why the Qarakhanids disappeared from Chinese accounts of the twelfth century: they may simply have been referred to by different names, including by the term "Uyghurs." 


\section{The Liao Envoy in Ghazna and the "Persians" from Northern India in Kaifeng}

Ghaznavid relations with China are usually associated with a Khitan envoy named Qul-Tonga or Kul-Tonga (Qultunkā), who was sent by Emperor Shengzong of Liao to the court of Sultan Mahmud in 1024. The story of the Liao envoy who arrived in Ghazna in 1026 or 1027 together with the Uyghur mission was recorded by several Muslim authors. ${ }^{1}$ Conversely, Chinese chronicles do not provide any information on Liao-Ghaznavid relations or the Liao envoy sent to Central Asia. At the same time, the section on India in the official history of the Song dynasty, Song shi recorded a mission to Emperor Taizong of Song (976-997) sent by a ruler of the Persian (Bosi) country located near Northern India that arrived in 984.

The history of Chinese relations with India is long and complex. The entire Indian subcontinent was called Tianzhu in Chinese chronicles, a primarily geographical designation that was used from the Later Han to the Song periods. Song historians also mentioned other names used for India, such as Juandu (India), Majiatuo (Magadha), and Poluomen (Brahman), and divided India into three zones: Bei Yindu (Northern India), Zhong Yindu (Central India), and Nan Yindu (Southern India). ${ }^{2}$ Song chroniclers counted six countries in the description of Northern India and one of these countries was called Bosi, a Chinese term for Persia and Persians.

This section deals with diplomacy and trade roads between China and Northern India and Islamic accounts on China in the tenth and eleventh centuries. I argue that Bosi, located by Song historians in or near Northern India, may refer to the Persianized Ghaznavid dynasty, and the envoy from this country was sent by the founder of the dynasty, Abu Mansur Sabuktigin.

\subsection{Journey to Ghazna}

The Khitan delegation headed by Qul-Tonga, who, judging by his name, was of Turkic origin, most likely started its journey from Shangjing (Supreme Capital) of Linhuang, located in modern-day Bairin Left Banner, Inner Mongolia. This expedition from Inner Mongolia to present-day Afghanistan began in 1024 and lasted $2-3$ years. The envoy first arrived in Turfan where another mission by

1 Zayn al-akhbār, ed. Ḥabībī, 191; Ṭabā’’ al-ḩayawān, ed. and trans. Minorsky, 19-21; Kitāb al-șaydana fi al-țībb, ed. and trans. Said, 141 , for the Arabic text, see 174 .

2 Song shi, 490: 14103, 14105. The entire Indian subcontinent during the Song period was also known as Wu Tienzhu (Five Indians) referring to Central, Eastern, Southern, Western and Northern India. This division was borrowed from the Brahman system. Guihai yuheng zhi, trans. Hargett, 265, n. 403, for the Chinese text, see 231. 
the Uyghurs joined the Khitans. ${ }^{3}$ The next destination was the Qarakhanid realm. No records remain of their stay in Turkistan. We know that they crossed the Qarakhanid realm from the Khitan letter. The letter was preserved in the Arabic translation provided by Marwazi. The Khitan envoy was of Turkic origin. Therefore, it can be assumed that the original letter was written in Turkic or translated into Turkic at the Khitan court:

Concerning the welfare [of the Qitāy Khan], to the Amir of Khurasan Mahmud Qarakhan:

The lord of the Heavens has granted to us kingdoms upon the face of the wide earth and placed us in possession of regions occupied by numerous tribes. In our capital we enjoy security and act according to our will. Anyone in the world who can see and hear cannot help seeking friendship and close relations with us. Our nephews from among the amirs of the nearer regions constantly and without exception send their envoys, and their letters and presents follow upon one another. He [Mahmud] until now has sent no envoy or messenger, while we hear of his excellence in strength and courage, of his outstanding position in might and elevation, of his supremacy over the amirs by awe, of his control of the provinces by might and authority and of his peace in his homeland according to his own will. As he enjoys such a glorious position it is a duty for him to write his news to the Supreme Khan whom there is none higher beneath the heavens, and to treat him with consideration according to his state. So we have taken the initiative, limiting overselves to the dispatch of this lightly equipped envoy rather than someone who would exceed him in rank and equipage, in view of the greatness of the distance and the length of time for covering it.

And as there happened to be an alliance with Qadir Khan [i.e. Yusuf Qadir Khan] through a noble lady from the bosom of my house who became married to his son Chaghri Tegin, and both houses became united through her, we have ordered Qadir Khan to open the road to our envoy to him [Mahmud] and to his envoy to ourselves, chosen from among men of sound judgement, intelligent and serious, so that we may inform him of how things stand with us, and communicate with him on what there is in the world, while establishing the custom of mutual donations, in friendship with him.

3 Minorsky assumed that the Uyghur mission was sent by the Ganzhou Uyghurs. For the discussion of this issue, see Chapter 4. 
The object in dispatching this envoy Qultunkā [Qul-Tonga or Kul-Tonga $]^{4}$ is to open the road of union and to fasten the ties of amity. ${ }^{5}$

It can be assumed that the joint delegation of the Khitans and the Uyghurs crossed and also probably stopped in Qarakhanid cities on their way to Ghazna. However, it is unclear whether the Qarakhanids accompanied them as far as the Ghaznavid realm. They did provide this service for their allies who sent delegations to China via their territories. However, it seems that it was a requirement from the Chinese side and may not have been necessary at the Ghaznavid court. Regardless, the Qarakhanids allowed the Khitan-Uyghur joint delegation to pass their realm and connected their eastern neighbors with the remote parts of the Islamic world. The Qarakhanids sought to create crossroads in their region with their foreign policy. They not only developed trade with China but also tried to introduce their neigbors to the Chinese market and vice versa. The existence of long-distance trade between China and the Ghaznavids during the rule of Sultan Mahmud can be proved based on a story about a merchant that was recorded by Niẓām al-Mulk:

They say that a merchant came to Sultan Mahmud's court of complaints, and complained against Mahmud's son Mas'ud, imploring justice and saying: "I am a merchant, it is a long time since I came here, and I want to return to my own city. I cannot go because your son has bought goods from me to the value of 6o,ooo dinars, and he has not given me the money. I request you to send the amir Mas'ud with me to the judge." Sultan Mahmud was vexed at the merchant's words and sent a harsh message to Mas'ud, saying: "I desire you either to pay this man due, or else to go with him to court so that judgment may be given according to the provisions of Muslim law." The merchant went to the judge's house and a messenger went to Mas'ud and delivered the message. Mas'ud was at loss to know what to do. He said to his treasurer: "See how much money there is in the treasury." The treasurer counted it, and said: "20,000 dinars." He said: "Take it to the merchant, and for the rest ask for three days grace." And he said to the messenger: "Tell the sultan that I have just given 20,000 dinars, and I will pay the rest after three days. I am standing

4 Minorsky assumed that the Khitan envoy could be a slave based on the reading of his name as Qul-Tonga. Tabā’i al-hayawān, ed. and trans. Minorsky, 21. It is unlikely that the official envoy would have the word "slave" $(q u l)$ as a part of the name. Qul can be the Arabization of the Turkic name Kul. I owe this comment to Étienne de la Vaissière.

5 Tabā'i al-hayawān, ed. and trans. Minorsky, 19-20, for the Arabic text, see * $7-{ }^{*} 8$. 
here with my cloak on and my loins girt, waiting for the sultan's command." Mahmud said: "Know for sure that you will not see my face until you pay the merchant in full." Mas'ud dared not to say anything further, so he sent people in all directions to ask for loans. By the time of afternoon prayer the 6o,ooo dinars had been paid to the merchant. When reports of this reached distant parts of the world, merchants from Chīn [Song], Khitāy [Liao], Egypt and 'Aden set out for Ghazna, bringing all the choicest goods in the world. ${ }^{6}$

Nizāam al-Mulk mentioned Chīn and Khitāy. Both terms could be used generally referring to China in Muslim sources but in this context the author wanted to point out that merchants arrived from the Song and the Liao realms. This passage also indicates the participation of the Ghaznavids in international maritime trade. Merchants from Egypt and Yemen mostly arrived in Ghazna by sea.

The Khitan diplomatic mission to Ghazna itself was not a success. Sultan Mahmud rejected the Khitan request for a marriage alliance on religious grounds. However, it seems that he was not interested in diplomatic relations with either Khitans or the Uyghurs. After several successful conquests in India, Sultan Mahmud had access to the sea and could reach Song China via maritime routes. Despite this, the mission had an impact on the development of geographical and ethnographical knowledge of China in the Islamic world.

\subsection{Images of China in Central Asia}

Major Central Asian works of the eleventh-twelfth centuries described the Khitan mission to Ghazna. For instance, the Saljuq scholar Marwazi provided the translations of the official letters sent by the Khitans and the Uyghurs to Sultan Mahmud and the detailed description of itinararies to Turfan, Liao and Song China. ${ }^{7}$ The court historian Gardizì depicted the answer of Sultan Mahmud. ${ }^{8}$ The polymath al-Bīrūnī, who also served at the Ghaznavid court, mentioned that he personally met the Khitan messenger (rasūl-i Qitāy) Qul-Tonga. ${ }^{9}$

China was usually known in early Islamic sources as al-Ṣin/Chīn or Chīnistān. After the Khitan-Uyghur joint mission to Ghazna Central Asian authors started actively applying the term Qitāy or Khitāy referring to China.

6 Siyāsatnāma, trans. Darke, 248-249.

7 Tabä’’ al-hayawān, ed. and trans. Minorsky, 18-20, for the Arabic text, see *6-*8.

8 Zayn al-akhbār, ed. Ḥabībī, 191.

9 Kitāb al-ṣaydana fí al-țībb, ed. and trans. Said, 141, for the Arabic text, see 174. 
Moreover, they divided China into different political and geographical regions. Marwazī, for example, pointed out that there are three parts (āqsām): al-Ṣin, Qitāy known as Khitāy, and Yughur and the greatest kingdom (mamlakat) was al-Ṣinn. ${ }^{10}$ Marwazìs description of China contains geographical, political, and ethnographic information. An astute reader may notice that the author referred to eleventh-century China when he provided information on land roads and distances, geographical and political divisions, diplomacy, and foreign relations. However, when he moved to the description of the sea roads and the ethnographic part it becomes obvious that he also used information from earlier records on China that were compiled during the Tang period. ${ }^{11}$ The same mix can be observed in other Muslim sources of the tenth-twelfth centuries that contain records on China. Therefore, it is sometimes difficult to distinguish between new and irrelevant information.

Paradoxically, al-Bīrūnī's records on China contain the most accurate information. His works are among the earliest accounts of Song and Liao China in the Islamic world. He obtained relevant information about China from the Khitan messenger and from persons who visited China. For instance, he mentioned a man named Ibrahim Sandani, who traveled in the desert of China (al-Ṣin) and shared what he saw and heard during his journey. He narrated a story about a big bird that lived between China and Zanj ${ }^{12}$ and fed on huge elephants called khutū. ${ }^{13}$ It seems that al-Bīrūnī was interested in the origin of $k h u t \bar{u}$. It was the name for a material used for knife handles and presented by the Khitan delegation to Sultan Mahmud of Ghazna. The Khitan messenger said that khutū is the forehead of a bullock and prized by people due to its ability to detect poison, as it becomes wet when brought close to toxic substances. ${ }^{14}$ Furthermore, al-Bīrūnī also mentioned some Chinese products that traded in the Ghaznavid realm and were well known in the Islamic world:

Ebony $(\bar{a} b n \bar{u} s)$ from the country of al-Nasa in China

Bezoar $(b \bar{a} d z a h r)$ from the borders of China

Gunpowder (thälj-i Sin̄i "Chinese snow")

10 Tabā’i al-hayawān, ed. and trans. Minorsky, 14, for the Arabic text, see *2.

11 For comparison, see the description of China in the tenth-century work Hudūd al-älam, trans. Minorsky, 83-86. Pavel Lurje identified that the original text used in Hudüd al-'álam for the description of China was composed in the second half of the eighth century. Pavel B. Lurje, "Description of the Overland Route to China in Hudud al-'Alam: Dates of the Underlying Itinerary," Ouya xuekan 欧亚学刊 6 (2007): 179-197.

12 Zanj is a term used by Muslim geographers for Southeast Africa.

13 Kitāb al-șaydana fì al-țībb, ed. and trans. Said, 141, for the Arabic text, see 174.

14 Ibid. 


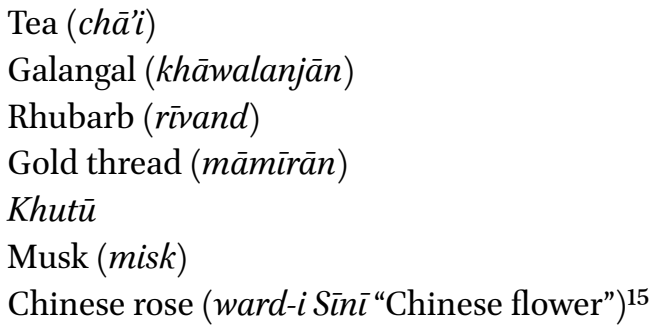

Most likely al-Bīrūnī would have had access to reports of travel to China that circulated in the region. For instance, he provided the following coordinates of the major cities of Song and Liao China in his Al-Qānūn al-Mas'üdi: ${ }^{16}$

TABLE 3 Coordinates of Chinese cities according to al-Bīrūnī

\begin{tabular}{|c|c|c|c|c|c|}
\hline Place names & $\begin{array}{l}\text { Long. } \\
\text { zaman }\end{array}$ & $\min$. & $\begin{array}{l}\text { Lat. } \\
\text { degrees }\end{array}$ & $\min$. & $\begin{array}{l}\text { Regions and } \\
\text { Countries }\end{array}$ \\
\hline $\begin{array}{l}\text { Banjū } \bar{a}^{\mathbf{a}} \text { - residence of Faghfūr }{ }^{\mathrm{b}} \\
\text { of China, named Tamghach }\end{array}$ & 125 & o & 22 & o & $\begin{array}{l}\text { al-Ṣīn [Song } \\
\text { China] }\end{array}$ \\
\hline Khan & & & & & \\
\hline $\begin{array}{l}\text { Kūfū - a city larger than the } \\
\text { capital Banjū }\end{array}$ & 127 & o & 21 & o & $\begin{array}{l}\text { al-Șīn [Song } \\
\text { China] }\end{array}$ \\
\hline Ūtkīn & 136 & 30 & 26 & o & Turks [Khitans] \\
\hline Qitā - in the northeast of al-Ṣinn & 148 & 40 & 21 & 40 & Turks [Khitans] \\
\hline
\end{tabular}

[China], its king is Qitā Khan

a Minorsky read it as Yanjū. Țabä’i $i^{\prime}$ al-hayawān, ed. and trans. Minorsky, 69. Marwazì recorded the city as Yanjūr. Ibid, 18 , the Arabic, text ${ }^{*} 7$.

b Faghfür or Baghbūr ("Son of God"), title of the emperor of China in Muslim sources used as the translation of the Chinese Tianzi "Son of Heaven."

Marwazì also mentioned these place names and recorded information of times for the voyage from the Qarakhanid cities to China. The journey from Kashghar to the Song capital Yanjūr (also can be read as Banjūr) took 13 o days.

\footnotetext{
15 Kitäb al-șaydana fi al-țībb, ed. and trans. Said, 13, 69, 101, 105, 138, 141, 300, 304-305, 336, for the Arabic text, see 19, 88, 125, 128, 169, 174, 338, 345-346, 381.

16 Al-Q̄ānūn al-Mas'ūdi, trans. Bulgakov and Rosenfeld, 450.
} 
The journey from Kashghar to the Khitan cities Ūtkīn and Ūjam (according to al-Bīrūnī Qitā) took 140 and 170 days respectively. ${ }^{17}$

Minorsky calculated the distances between the major places provided by al-Bīrūnī and compared to the information recorded by Marwazì. He suggested that Yanjū may refer to Luoyang, the Western Capital (Xijing) of the Song that had been previously known as Yongzhou. He also assumed that Küfū could be identified with Kaifeng, the Eastern Capital (Dongjing) of the Song. He located Ütkin in present-day Zhuolu County in the northwest of Hebei Province and identified Ujam (Qitā) with Linhuang, the Supreme Capital of the Liao Empire. ${ }^{18}$ However, Kaifeng was known during the Song period as Bianjing (previosly Bianzhou) that served as the main residence of the Northern Song emperors. Therefore, Banjū is probably the more correct reading and may refer to Bianjing (Kaifeng) rather than to Luoyang.

The journey of the Liao envoy Qul-Tonga to Ghazna did not receive much attention in the Sinitic world. At least, the official history of the Liao dynasty as well as other contemporary Chinese sources have no information about this delegation. The reason for this is unclear. It can be only suggested that the Mongols who compiled Liao shi omitted this information for some reason, such as unwillingness to record an unsuccessful delegation sent by the Liao Emperor. However, this idea cannot be confirmed. At the same time, the official history of the Liao dynasty is one of the shortest standard histories of China, which demonstrates that historians already suffered from a lack of sources on the history of the Khitans in the fourteenth century. Therefore, even if there was any record on the Khitan mission to Ghazna it probably did not survive until the time the Khitan history was compiled. It could be also a secret mission and for this reason was not described in Chinese sources. We have an earlier example in the history of Sino-Islamic relations when the Chinese mission to Baghdad in 785 was not recorded in official sources. We know about this event only due to the discovery of the tomb stele of Yang Liangyao, a Tang dynasty eunuch, who was sent as an envoy to the Caliph via the sea road from Guangzhou to the Persian Gulf. Angela Schottenhammer suggested that it was a secret mission to ask the Arabs for military support against the Tibetans and for this reason, remained unrecorded in both Chinese and Muslim sources. ${ }^{19}$

17 Tabā'i al-hayawān, ed. and trans. Minorsky, 18, the Arabic text, * 7.

18 For the details, see Ibid, $68-76$.

19 Angela Schottenhammer, "Yang Liangyao's Mission of 785 to the Calip of Baghdād: Evidence of an Early Sino-Arabic Power Alliance?" Bulletin de l'École française d'ExtrêmeOrient 101 (2015): 177-241. 
Similar to the Khitan mission to Ghazna, the journey of a Persian envoy from Northern India to the capital of Song China was described only in Chinese sources and ignored by Muslim authors.

\subsection{Journey to Kaifeng and What Was Bosi?}

The Song capital in Kaifeng that was known as Bianjing and Dongjing (Eastern Capital) at that time ranked among the most flourishing metropolises in the world and from the very beginning of the Song period attracted an array of foreign travelers and merchants. Official delegations from different parts of the world came to Kaifeng in order to encourage trade relations with Song China. Thus, according to Chinese sources, a delegation from Bosi arrived at the Chinese court during the rule of Emperor Taizong. This Persian country was not located in Iran but rather in the westernmost border of Northern India.

The Chinese term Bosi derived from the designation Pars and originally applied to the Sassanian Empire (226-651) ${ }^{20}$ According to Wei shu, the Bosi country (the Sassanian Empire) was previously known as the country of Tiaozhi. ${ }^{21}$ Tiaozhi is believed to be a short or corrupted form of Antioch and may refer to the Seleucid Empire (312 BCE-63 BCE). ${ }^{22}$ The term Bosi was also used to refer to the Sassanian court-in-exile in the southern Hindukush during the seventh-eighth centuries. ${ }^{23}$

The term Bosi continued to be used even after the collapse of the Sassanians until the Song period. Tang sources clearly stated the borders of the Bosi country. For instance, according to Jiu Tang shu, in the east, Bosi was connected with Tokharistan (Tuhuoluo) and Sogdiana (Kang), in the north with the Khazar Turks (Tujue zhi Kesa) in the northwest with the Byzantine Empire (Fulin), and in the southwest with the Persian Gulf (Dahai). ${ }^{24}$ The term Bosi applied not only to the geographical region, but also to foreign merchants and products coming from Persia, or in some cases from other places of the Islamic world. ${ }^{25}$ Berthold Laufer claimed the existence of another country and people that were known as Bosi during the Tang period and earlier that was probably

20 For Chinese-Sassanian relations, see Matteo Compareti, "The Last Sassanians in China," Eurasian Studies 2, no. 2 (2003): 197-213.

21 Wei shu, 102: 2270-2272.

22 Wang Tao, "Parthia in China: Re-examination of the Historical Records," in The Age of the Parthians. The Idea of Iran, ed. Vesta S. Curtis, and Sarah Stewart (London: Tauris, 2007), vol. 2 , 91.

23 Domenico Agostini and Sören Stark, "Zāwulistān, Kāwulistān and the Land Bosi 波斯 On the Question of a Sassanian Court-In-Exile in the Southern Hindukush," Studia Iranica 45 (2016): $17-38$.

24 Jiu Tang shu, 198: 5311; the same description is given in Xin Tang shu, 221: 6258.

25 Schottenhammer, "Transfer of Xiangyao," 124-125. 
located in Southeast Asia on the border of Burma and Malayan Kunlun and belonged to the Malayan group. Therefore, he concluded that the term Bosi should not be always automatically translated as Persia. ${ }^{26}$ However, Chinese sources never indicated the existence of the second Bosi, and this term can also refer to a possible Persian diaspora that settled in this region. ${ }^{27}$ This kind of Bosi also existed during the Song period; however, in order to make a distinction between the two Bosi, Song chroniclers probably applied a slightly different name for a region located in Southeast Asia. They mentioned a region or people called Bosilan (possibly from Pārsiān) located in the southeast of the Khmer Empire (802-1431). ${ }^{28}$

From the Song period, the designation Bosi for Persia was mainly replaced by the term Dashi, a name initially applied to the 'Abbasids and Arabs, and later to all Muslims regardless of their origin and apparently to non-Muslim groups of the Islamic polities. According to Song shi, "Dashi was originally another kind of Bosi."29 However, during the Song period, Bosi was still in use as a geographical designation and referred not to Iran, but to the region near Northern India.

\subsection{Bosi and Northern India}

The section on India in Song shi was included in Chapter 490 related to waiguo (outside countries) and India was grouped with different polities in Central Asia, Iran, and Arabia, which clearly illustrates Chinese perceptions of the "West" during the Song period. ${ }^{30}$ India is also depicted in the Song map Hua yi tu (Map of Chinese and Non-Chinese Countries) that I discuss in Chapter 3 (Figures 3.1. and 3.2.).

Song chroniclers recorded fifteen polities located in India: six countries in Northern India, eight in Central India, and one in Southern India. The description of Northern India mainly consisted of previously well-known geographical terms.

施護者, 烏塤晒國人。其國屬北印度, 西行十二日至乾陀羅國, 又 西行二十日至暴誐囉賀囉國, 又西行十日至嵐婆國, 又西行十二日 至誐惹暴國, 又西行至波斯國, 得西海。自北印度行百二十日至中 印度。31

Berthold Laufer, Sino-Iranica. Chinese Contributions to the History of Civilization in Ancient Iran: With Special Reference to the History of Cultivated Plants and Products (Chicago: Field Museum of Natural History, 1919), 468-487.

27 Schottenhammer, "Transfer of Xiangyao," 125.

28 Song shi, 489: 14087.

29 大食國本波斯之別種。Song shi, 490: 14118.

$30 \quad$ Song shi, 490: 14103 .

31 Song shi, 490: 14104-14105. 
Shihu [Danapala] ${ }^{32}$ was a person from the Wuxunnang [Uddiyana] state. His state belongs to Bei Yindu [Northern India], from which traveling for twelve days westward one reaches the Qiantuoluo [Gandhara] state, in twenty days more one reaches the Nangeluoheluo [Nagarahara] state; in ten days more one reaches the Lanpo [Laghman] state; in twelve days more one reaches the Erenang state; and traveling further westward one reaches the Bosi [Persia] state and finishes in Xihai [Western Sea]. ${ }^{33}$ From Northern India, if one travels one hundred and twenty days, he reaches Central India.

These place names in northern India, excluding Erenang and Bosi, were also mentioned in earlier Chinese sources. The description started from Wuxunnang, which is Uddiyana (Udyana) in the north of Punjab in presentday Pakistan, also known as Wuchang during the lifetime of the Chinese monk Faxian (337-422). ${ }^{34}$ Qiantuoluo, which was visited not only by Faxian, but also by the Chinese monk Xuanzang (6o2-664), who traveled to India during the Tang period, refers to the ancient kingdom of Gandhara situated in the Peshawar valley of present-day Pakistan. ${ }^{35}$ Nangeluoheluo, which is the Nagarahara kingdom and was known as Najieluohe during the time of Xuanzang, is located in the Jalalabad area of present-day Afghanistan. ${ }^{36}$ Lanpo corresponds with Laghman in present-day eastern Afghanistan. ${ }^{37}$ Erenang was not recorded in earlier sources but most likely it refers to a region in present-day Afghanistan. Song chroniclers mentioned all places in northern India, which mainly correspond to present-day Pakistan and Afghanistan from the southeast to the northwest, and located the Bosi country in the westernmost part of Northern India.

A mission dispatched by the Bosi ruler arrived at the Song court in June, 984. ${ }^{38}$ This mission was led by an envoy named Aliyan [LMC: ?a-li?jian], possibly Persian Aliyar or Alijan, who arrived at the court together with the monk Yongshi from Poluomen (Brahman). Aliyan was referred to by the Song

32 Shihu or Danapala (?-1018) was an Indian monk served as a translator of Buddhist texts at the Song court from 980. Sen, Buddhism, Diplomacy, and Trade, 112-113, 121.

33 This is probably the Persian Gulf or the Arabian Sea.

34 Fa guo ji, trans. Legge, 28-29. Also see Da Tang Xi yu ji, trans. Beal, 119-135. For the place of origin of Danapala, see Sen, Buddhism, Diplomacy, and Trade, 121.

35 Da Tang Xi yu ji, trans. Beal, $3^{1-}{ }^{2}$.

36 Ibid, 91-94.

37 Ibid, 9o-91.

38 Song shi recorded that the envoy came to the court sometime between 984 and 988. Song shi, 490: 14105; Song huiyao jigao, Fanyi 4: 90. 
chroniclers as a person of different faith waidao (foreign doctrine), meaning non-Buddhist or non-Confucian. The Bosi envoy provided the following information about his country:

本國王號黑衣, 姓張, 名哩沒, 用錦綵為衣, 每遊獵, 三二日一還 國。署大臣九人治國事。無錢貨, 以雜物貿易。其國東行經六月至婆 羅門。39

The ruler of my state is called Heiyi [Heyi Dashi "Black-robed Dashi”], his family name is Zhang and personal name is Limei; ${ }^{40}$ he wears clothes of colored brocade; whenever he goes hunting, he returns every $2-3$ days. He appoints nine high officials to manage state affairs. There are no coins and various products are used for trade. If one goes eastward from this state, in six months one reaches Poluomen [Brahman].

The term Heiyi is a shortened version of the Chinese name Heiyi Dashi "Blackrobed Dashi," used originally for the 'Abbasids, but here meaning "Muslim." It is also possible that the envoy would have introduced his ruler as an appointee of the 'Abbasid Caliph. The Caliphs were considered the head of the religious establishment in the eastern provinces of the former 'Abbasid Caliphate and retained important moral authority and symbolic standing as heads of the Muslim community. The early Turko-Islamic dynasties, as well as the Ghaznavids, sought recognition by the Caliphs from the very beginning of their rule in order to provide moral and religious sanction for their conquests. Sabuktigin, in his Pandnamma written for his son Mahmud, stated that his origin was from Turkistan, from a tribe called Barskhan, and the name of his father was Jūq with a title Barskhan. ${ }^{41}$ Sabuktigin was known by the title Amir ${ }^{42}$ and the envoy probably introduced him as Amir Sabuktigin, a son of Jūq.

It can be assumed that the term Bosi in Song shi also applied to the Samanid Empire. However, the Samanids were centered in Transoxiana, the region that was known in Song sources as Dashi, so they could not have been located near Northern India as identified by Chinese chroniclers. The itinerary used by the Bosi envoy was hardly suitable for the Samanids. The envoy came together with the monk from Poluomen, which is located in the east or the southeast, six

39 Song shi, 490: 14105-14106.

40 In Wenxian tongkao and Song huiyao jigao it is given as Lilimei, see Wenxian tongkao, 338: 2655-3; Song huiyao jigao, Fanyi 4: 89.

41 Muhammad Nazim, "The "Pand-Nāmah" of Subuktiginn," The Journal of the Royal Asiatic Society of Great Britain and Ireland 3 (1933): Persian text 610, English translation 621.

Nazim, "The "Pand-Nāmah," 6o5-6o7. 
months' journey from Bosi. The journey between Bosi and central India also took around six months. Therefore, Poluomen most likely referred to a region in central India. The monk from Poluomen said that his country was known as Lide. ${ }^{43}$ Friedrich Hirth assumed that it refers to the country of Lata (Larike) in southern Gujarat on the Gulf of Cambay. ${ }^{44}$ The monk from Poluomen reported that they went to the east, which corresponds to the modern northeast direction, and reached Dashi (Muslims, i.e., the Qarakhanids centered in Kashghar) in six months, then Xizhou (Turfan) in two months and Xiazhou (present-day northern Shaanxi) in three months. ${ }^{45}$ The journey from Bosi to Song China took almost a year and the envoy crossed the territories of Kashgharia and Turfan. The Samanids were involved in a military confrontation with the Qarakhanids in this period and it is unlikely that the Qarakhanids would allow any mission of the Samanids to pass through their territories. Moreover, the Bosi envoy reported that they did not use money in commercial affairs. It can be assumed that the Bosi ruler did not mint coins; otherwise the Chinese would record the description of coins following the usual practice. This passage cannot be associated with the Samanids but may refer to the Ghaznavid situation at that time as Sabuktigin started his own mints not earlier than in 990. ${ }^{46}$

The Chinese scholar Qian Boquan suggested that this Bosi could refer to the Qarakhanids. He claimed that the term Heiyi, which comes from Heyi Dashi, corresponds to the Qarakhanids. He considered that Song chroniclers might be confused about the direction taken by the Bosi envoy and the Poluomen monk. He also assumed that the envoy Aliyan could be a Nestorian. He relied on Tang sources, which used the term Bosi si (Bosi temple), referring to Nestorian churches. Therefore, the term waidao, used for the faith of Aliyan may refer to Nestorianism. ${ }^{47}$ However, the term waidao may also simply refer to Islam and it is unlikely that Song chroniclers included a description of the Qarakhanids in the section of India. The Bosi envoy went east, which is actually northeastward together with the Poluomen monk and reached Dashi that refers to the Qarakhanid realm, as it was just two months away from Turfan. It is clear that Bosi and Dashi were two different polities. This statement also becomes clear from the additional information provided in Song huiyao jigao. According to

\footnotetext{
43 Song shi, 490: 14105 .

44 Zhu fan zhi, trans. Hirth and Rockhill, 112, n.1.

45 Song shi, 490: 14105.

46 Syed Jabir Raza, "Coinage and Metallurgy under the Ghaznavid Sultan Mahmud," Proceedings of the Indian History Congress 75 (2014): 224.

47 Qian Boquan 钱伯泉, "Dashi, Heiyi Dashi, Kalahan wangchao kaoshi 大石、黑衣大 石、喀喇汗王朝考实 [Study on Dashi, Heiyi Dashi and the Qarakhanids]," Minzu yanjiu 民族研究 1 (1995): 75-76.
} 
this source the envoy Aliyan provided more information about his country that was omitted in Song shi:

男子以白疊布為衣, 婦人豪富者著大食國錦綺, 貧下止服絹布。種陸 田，而無稻糯。土宜絲䖯、羊馬、果實。48

Men wear clothes made from white cotton fabric; women who are powerful and wealthy wear brocade and patterned silk from the Dashi state; poor people wear clothes only from cotton-like lustring. They plant in dry fields and do not have glutinous rice. The land is suitable for silkworms, sheep, horses, and fruits.

In this passage, Dashi most likely refers to the Samanids in Transoxiana, which were the most notable centers of fabric production, rather than to the Qarakhanid realm. However, it is clear that Bosi was distinguished from the Qarakhanid as well as from the Samanid realms. The Qarakhanids were known not only as Dashi but also as Shule (Kashghar) ${ }^{49}$ and later after the conquest of the Khotan kingdom as Yutian (Khotan). ${ }^{50}$ When the Qarakhanids split into western and eastern parts, the western Qarakhanids centered in Transoxiana continued to be known as Dashi and the eastern Qarakhanids were called Yutian. The term Bosi was never applied to the Qarakhanids.

Therefore, the Bosi state mentioned in the section of India by Song chroniclers most likely refers to the newly founded Ghaznavid dynasty centered in Ghazna. The founder of this dynasty, Sabuktigin, continually extended the borders of the state from the very beginning of his rule. In 977, the first year of his reign, he conquered Bust, which was one of the main cities of Sijistan as well as the city Qusdar in Sind, and then the entire province of Qandahar. In the following years, he attacked the Hindu Shahi king Jayapal several times and established his power in almost all territory west of the Indus. ${ }^{51}$ Sabuktigin probably sought to initiate relations with Song China and sent his envoy via highways that connected India with China. Song emperors issued special edicts in order to keep the peace on the roads linking India and dispatched monks in search of Buddhist dharma. As a result, in the tenth and eleventh centuries, one hundred thirty-eight Chinese monks visited India, and around

\footnotetext{
48 Song huiyao jigao, Fanyi 4: 89.

49 Song shi, 490: 14106-14107.

50 Song shi, 490: 14107-14109.

51 For the Sabuktigin, conquests see Andre Wink, Al-Hind: The Making of the Indo-Islamic World. Vol II: The Slave Kings and the Islamic Conquest, 11th-13th Centuries (Leiden: Brill, 1997), 129.
} 
eighty Indian monks arrived in China. ${ }^{52}$ Therefore, the Ghaznavid envoy came together with the Indian monk, and when they arrived in Turfan an envoy of the Uyghurs accompanied them further to China. ${ }^{53}$ The "Persian" envoy probably presented products of his country such as horses, sheep, silkworms, and fruit, which were recorded by Chinese chroniclers.

Why did Song chroniclers apply the term Bosi to the Ghaznavids? Taking into account the fact that the administrative apparatus of the Ghaznavids were formed by Persians, it can be assumed that the envoy was a Persian bureaucrat or a religious leader (waidao) and the official document which he brought to the Chinese court was also written in Persian. Moreover, Sabuktigin continued to formally recognize the supremacy of the Samanids, which was probably also indicated in the written document. Therefore, the Ghaznavids were Persians in the Chinese perception.

This is the only mission from Bosi in northern India that was recorded in Song sources. However, I presume that the Ghaznavids continued to send envoys to Song China, especially after the further expansions into India, which opened direct access to maritime trade, and the Ghaznavids became middlemen between Arabia and China. Foreign envoys, merchants, and travelers who arrived from the Islamic world via sea roads were generally recorded by Chinese chroniclers as Dashi. Therefore, it is not always possible to know the exact origin of the Muslim envoys, who arrived at the Song court. The Chinese chroniclers who compiled Song shi recorded that "the subordinates of Dashi are varied in name."54 Therefore, as soon as the Ghaznavids started to use maritime roads in trade with China, they were also viewed as a part of the Islamic world and referred to as Dashi.

\subsection{Other Chinese Historical Records about the Ghaznavids}

The Song official Zhou Qufei (1135-1189), who served in China's southwest and left the geographical work Lingwai daida (Notes from the Lands Beyond the Passes), recorded that the term Dashi is a collective appellation for more than a thousand countries and provided descriptions of a few of them, including the Ghaznavid realm. ${ }^{55}$ Zhao Rugua, a Song historian, who served as a supervisor of maritime trade in Quanzhou and wrote a two-volume book on foreign countries and trade Zhu fan zhi (Records of Foreign Peoples), provided

$5^{2}$ Sen, Buddhism, Diplomacy, and Trade, 102-105, 110-111. For Indian monks and translators in Song China, see also Ibid, 120-125.

53 Song huiyao jigao, Fanyi 4: 90.

54 Song shi, 490: 14121.

55 Lingwai daida, 3: 53-54; for the German translation, see Lingwai daida, trans. Netolitzky 1977, 45-46. 
a list of twenty-four Dashi countries. The Ghaznavid realm was also on his list and referred to as Jicini (Ghazna). Zhao Rugua finished his book around 1225 when the Ghaznavid dynasty no longer existed. Therefore, his description of the Ghaznavids was based mainly on earlier information recorded by Zhou Qufei. However, Zhao Rugua probably also relied on other earlier sources that have not survived. He provided a description of Sultan Mahmud, which is not available in the geographical work of Zhou Qufei:

王手臂過膝。有戰馬百匹, 各高六尺餘。騾數十匹, 亦高三尺。出則 更迭乘之, 所射弓數石, 五七人力不能挽。馬上使鐵鎚, 重五十餘 斤。大食及西天諸國皆畏焉。56

The king's arms reach below his knees. He has one hundred head of warhorses, each more than six chi high and several dozen heads of mules, three chi high. When he marches out, he alternates which one he rides; he shoots a bow that weighs several dan, and even with the effort of five or seven men it is not possible to bend it. On horseback, he uses an iron hammer, which weighs more than fifty jin. All countries of Dashi [Muslims] and Xitian [India] fear him.

Zhao Rugua probably used earlier sources that left records on Sultan Mahmud of Ghazna, which was provided by merchants, travelers, and possibly envoys from the Ghaznavid realm. The description of the people of Ghazna and their customs, the climate, and products of this place is typical for official records on foreign countries, which were not well known in Song China and were usually obtained directly from ambassadors. Therefore, as a Song official, Zhao Rugua, as well as Zhou Qufei, could easily have had access to documents with the same accounts of Ghazna. However, I was not able to find any other source with this data. In addition to information that he collected during his official career, Zhou Qufei also used a famous geographical treatise known as Guihai yuheng zhi by Fan Chengda (1126-1193). ${ }^{57}$ Fan Chengda did not mention any data about Ghazna in his work, and information about the Islamic world was given only in a short supplementary entry, in which Muslim countries (Dashi) were categorized as man, a Chinese ancient term applied to foreigners

$5^{6}$ Zhu fan zhi, 19-20; for the English translation, see Zhu fan zhi, trans. Hirth and Rockhill 1911, 138. Hirth translated Xitian simply just the west. Xitian was one of the names of India in Chinese sources.

57 Guihaiyuheng zhi, trans. Hargett, XL. 
in south and southwestern China and commonly called nanman (southern barbarians). 58

Friedrich Hirth assumed that some stories about Sultan Mahmud were still well known among Muslim traders during the time of Zhao Rugua.59 According to the Chinese geographical treatise, the Ghaznavid realm could be reached in one hundred and twenty days from Mirbat, located in modern-day Oman. ${ }^{60}$ Therefore, it can be assumed that merchants from Arabia stopped at the Ghaznavid seaport on their way to China. The Chinese officials mentioned some local products of the Ghaznavid realm, which were probably also traded and brought as diplomatic gifts to China. The list of products includes "gold, silver, yиenuo cloth, golden brocade, camel hair in different colors, flower colored glass, storax oil, limonite, and bezoar stones." 61

It can be concluded that the Chinese term Bosi, meaning Persia and Persians and originally applied to Iran, was used to refer to a region in Northern India during the Song period, which refers to the realm of the Persianized Ghaznavid dynasty. The founder of the Ghaznavids, Abu Mansur Sabuktigin, sent an envoy jointly with the Brahman monk, who was probably from the country of Lata in southern Gujarat. The country of the Brahman monk was located six months' journey away from Bosi. They jointly traveled almost a year to China crossing Central Asia, particularly the territories of the Qarakhanids and the Xizhou Uyghurs, and arrived at the Chinese court in 984 .

The overland road that connected India with China was safe and often used by Buddhist monks during this period. Song emperors, in order to legitimize their authority, patronized Indian and Chinese monks and issued edicts to maintain the safety of the roads used by pilgrims that were terminated during the post-Tang period. Some eminent Indian monks also served at the Chinese court. Therefore, it can be concluded that the Brahman monk, in addition to his own mission, also provided guidance to the "Persian" envoy. These conditions made the Indian road to China the most beneficial for the Ghaznavid ruler than routes through Transoxiana, which was involved in the Samanid-Qarakhanid confrontation.

Chinese chroniclers mentioned only this mission from the "Persian" country in Northern India, which came by the overland road. Further expansion of India, started by Sabuktigin and continued by his son Mahmud, connected the

$5^{8}$ Ibid, 231-232, for the Chinese text, see 265 .

59 Zhu fan zhi, trans. Hirth and Rockhill, 139, n.2.

6o Zhufan zhi, 19 .

61 金銀、越諾布、金絲錦、五色駞毛段、碾花琉璃、蘇合油、無名異、摩娑 石。Zhufan zhi, 20. 
Ghaznavid realm with the Indian Ocean and opened access to the Sino-Indian trade network. The Ghaznavid ambassadors and merchants started to arrive in China by the maritime roads; therefore, they were grouped together with other Muslims under the term Dashi. Moreover, al-Bīrūnī recorded that he obtained some records about China from seafolk ( $\bar{a} h l-i b a h r)$ that proves the existence of maritime networks with China. For instance, he wrote:

Seafolks [al-bahriyūn $]$ say that kūlān [or kawlān $]^{62}$ grows on riversides of China, where the rivers advance and recede. Its root is called khäwalanjān [galangal], which is brought from China. ${ }^{63}$

Song officials Zhou Qufei and Zhao Rugua, who provided the description of the Ghaznavid realm in their works, probably obtained information from Ghaznavid ambassadors or merchants who arrived in China by sea as well as from earlier sources that have not survived.

\section{Sultans and Rum: Saljuq Missions to Northern Song China}

Any research on Saljuq history is mainly based on Muslim and Christian sources. ${ }^{64}$ Chinese primary and secondary sources have usually not been consulted. However, Chinese official sources of the Song dynasty recorded several envoys that may refer to the Great Saljuqs and the Saljuqs of Rum offering unique information that cannot be obtained from other sources.

It has been mentioned that the Turks were known to China by the autonym Tujue, which was used from the sixth until the middle of the tenth century. The mass conversion among the Turks reflected their representation in the Sinitic world and the name Dashi, meaning Muslims, applied to them as a generic term. The Saljuqs were also viewed as a part of the Islamic world

62 This is a herbaceous part of cyperus.

63 Kitāb al-șaydana fi al-țībb, ed. and trans. Said, 182, for the Arabic text, see 221. Regarding the word "seafolks," in the original Arabic text the word is written as al-nahwiyūn, therefore, Said translated it as "grammarians." Karimov translated the word as "seafolk" based on the Persian translation of Kitäb al-șaydana. In the Persian text the word is translated as ăhl-i bahr (seafolk). It means that the translator read the Arabic word as al-bahriyun (seafolk). Kitäb al-șaydana fì al-țībb, trans. Karimov, 529 and n. 15. In the Arabic text edited by Zaryab the word is also written as al-bahriyūn following the same approach. Kitāb al-șaydana fí al-țībb, ed. Zaryab, 334 and 335, n. 8.

64 Some materials used in this section were initially published in: Dilnoza Duturaeva, "Cengtan and Fulin: The Saljuqs in Chinese Sources," Crossroads: Studies on the History of Exchange Relations in the East Asian World 15 (2017): 29-48. 
and were recorded in Chinese sources generally as Dashi. This section argues that descriptions of Cengtan in Chinese official chronicles refer to the Saljuq Empire centered in Iran and that envoys from Fulin were dispatched by the Saljuq Sultanate in Anatolia.

\subsection{The Saljuq Empire in Chinese Sources}

The official history of the Song dynasty Song shi has a section on the state of Cengtan (LMC. tshəăy-than), which was mentioned only in sources for the Song history and did not appear in sources for other periods. ${ }^{65}$

The first scholars who attempted to identify the location of Cengtan were Friedrich Hirth and William Rockhill. They suggested that Cengtan is the same as Cengba (Zanzibar) mentioned in Zhu fan zhi. ${ }^{66}$ The Japanese scholar Fujita Toyohachi rejected this view and assumed that Cengtan was a Chinese transliteration of the main Saljuq title Sultan, and based on its geographical location claimed that Cengtan should refer to the Saljuq Empire. ${ }^{67}$ Some Chinese researchers have recently tried to locate Cengtan in Arabia. ${ }^{68}$ However, in Chinese scholarship, it is generally accepted that Cengtan refers to the Saljuq realm. ${ }^{69}$

The description of Cengtan in Song shi was taken from earlier sources of the Song period, which contain some crucial differences. One of the earliest extant descriptions of Cengtan can be found in Qingbo biezhi (Other Miscellaneous Notes from the Gate of Qingbo) compiled by Zhou Hui. Zhou Hui was a Song official who lived near the Qingbo gate in Hangzhou for many years after he retired. This gate served as one of the important entry points for ships from foreign countries. Zhou Hui left records on foreign countries and peoples that he probably obtained from merchants, envoys, travelers, interpreters, and many others who arrived in Hangzhou:

65 Song shi, 490: 14122-14123; this passage was translated into English, see Zhu fan zhi, trans. Hirth and Rockhill, 127, n. 4.

66 Zhu fan zhi, trans. Hirth and Rockhill, 127, n.4.

67 Fujita Toyohachi 藤田丰八, Zhongguo Nanhai gudai jiaotong congkao 中国南海古代交 通丛考 [Collection on relations between China and Lands of the Southern Sea], trans. He Jianmin 何健民 (Shanghai: Shanghai shangwu yinshuguan, 1936), 222.

68 Zhou Yunzhong 周运中, "Songdai jiaotong Zhongguo de Cengtan guo kao 宋代交通中 国的层檀国考 [On Cengtan during the Song dynasty], Hai jiao shi yanjiu 海交史研究 2 (2014): $27-35$.

69 Zhang Xinglang 张星烺, Zhong Xi jiaotong shiliao huibian 中西交通史料汇编 [Compilation of Historical Sources on Relations between China and the West] (Beijing: Zhonghua shuju, 1977), vol. 2, 256-259; Chen et al., Gudai Nanhai diming huishi, II, 1047, 1076; Lu, "Songdai Cengtan," 32. 
層檀, 南海旁國也。國城距海二千里, 海道須便風百六十許日, 書夜 行。經勿巡、古林、三佛齊國乃至廣州。國主名亞美羅亞眉蘭, 傳國 五百年, 十世矣。春冬暖。貴人以好越布纏頭, 服土產花綿白疊布, 不服綾羅絹帛, 出入乘象馬。官有月俸。其法輕罪杖, 重者死。有 稻、麥、粟、胡羊、山羊、沙牛、水牛、駝、馬、魚、犀、象、熏 陸、沈水香、血竭、沒藥、鵬砂、阿魏、䔡合 香、真珠、玻璃、葡 萄、千年栗、密沙華三酒。交易用官鑄錢, 三分其齊, 金銅相半而加 銀一分，禁私鑄。人之語音如大食國云。70

Cengtan is a neighbor state of the Southern Sea lands. The state city is 2 ,0oo $l i$ from the seaside; ${ }^{71}$ the sea road takes around 16 o days if one travels day and night with a favorable wind. It passes by Wuxun [Mazun], ${ }^{72}$ Gulin [Kollam], ${ }^{73}$ and Sanfoqi [Srivijaya] and goes so far as to Guangzhou [Canton]. The name of the ruler is Yameiluo Yameilan; [his family] handed down the state power for five hundred years and ten generations. ${ }^{74}$ Springs and winters are warm. The noble people wear turbans of fine muslin, clothing made from local flowered brocade and cotton fabric; they do wear thin patterned fabric or silk; when they go out and come in they ride elephants and horses. Officials receive monthly

70 Qingbo zazhi: Qingbo biezhi, juan zhong 141, 142.

71 Alp Arslan resided in Ray, Malik Shah I in Isfahan. At the same time, by 1055 the Saljuqs captured Baghdad and established themselves as the new protectors of the 'Abbasid Caliphate and Sunni Islam. Therefore, the description of the Cengtan capital most likely refers to Baghdad located on the banks of the Tigris, which empties into the Persian Gulf, and has a warm desert climate with mild winters. According to $\mathrm{Xu}$ zizhi tongjian changbian, 225: 5469 the city was located 20,00o li from the Southern Sea (Nanhai), the same source in another chapter recorded that it was located 20 li from the seaside, see $X u$ zizhi tongjian changbian, 332: 7998; for the reference of 20 li, also see Song shi, 49o: 14122. According to Wenxian tongkao, 332: 2612-2 the city was located 2,0oo li from the sea. I suppose that the Song shi information about the distance is more plausible, the compilers had access to different sources.

$7^{2}$ Wuxun (Mazun) is Sohar in modern Oman, one of the important trade ports located on the maritime road between the Islamic world and China.

73 Gulin (Kollam) is an old seaport and city situated on the Malabar Coast of southwestern India.

74 Hirth identified Yameiluo Yameilan [LMc. Pja:'-mi'-la-Pja:'-mi-lan] with Amìr-i Amïrān (Emir of Emirs), Zhu fan zhi, trans. Hirth and Rockhill, 127, n. 4. Some Saljuq Amirs used this title. For instance, 'Uthman, the uncle of the Saljuq Sultan Malik Shah I (1072-1092), who was a governor of Saklakand in Tukharistan was known as Amìr al-Umarā. Al-Kāmilfí al-ta'rīkh, ed. Tornberg, vol. 10, 53. It can be also a corruption of the title Amir al-Mu'minin, which was borne by the Caliphs. The Saljuq ambassadors could introduce the Caliph as the spiritual ruler. The sentence "they had ruled the state for five hundred years and ten generations" may refer in this context to the 'Abbasid Caliphs. 
salaries. By their law, minor offenses are punished with flogging and serious crimes with death. They have rice, wheat, millet, barbarian sheep, goats, ox, buffalo, camels, horses, fish, rhinoceros [can be also translated as rhino horns], elephants [can be also translated as ivory], frankincense, agarwood, dragon's blood [bright red tree resin], myrrh, borax, asafoetida, storax, pearls, glass, raisins, dates and three kinds of wine named $m i$, sha, and hua. ${ }^{75}$ In commerce they use coins minted by the officials; they consist of three parts: gold and copper in equal proportion and one part of silver; it is forbidden to mint coins privately. The sound of their language is similar to that which is spoken in the Dashi state.

The author also added at the end that officials who recorded information about foreign envoys usually described products and commodities presented by foreigners. Descriptions of territories and customs are usually omitted. But the Cengtan records contained this kind of information. It shows that at the Chinese court Cengtan was unknown, therefore, officials sought to compile a picture of this place and its people as much as possible. ${ }^{76}$

The same description of Cengtan, with some changes and additional information, appeared in Xu zizhi tongjian changbian compiled by Li Tao. Cengtan was recorded as Dashi Cengtan guo (the Muslim Cengtan state) and its capital was situated 20,00o li from the Southern Sea. The list of commodities excluded millet and agarwood but included costus root. Moreover, it was stated that in 1071, the ruler of Cengtan sent an envoy to the Song court for the first time, and then did so again in 1081 and 1083 . He also mentioned the Cengtan envoy Cengjiani ${ }^{77}$ with the Chinese title baoshun langjiang (Maintaining Submission Commandant), ${ }^{78}$ who came to the Chinese court twice and received imperial gifts, as well as 2,00o liang of silver. ${ }^{79}$ Baoshun was a laudatory epithet commonly prefixed to titles of nobility and friendly alien rulers. For instance, Qarakhanid and Uyghur Khagans also received from the Song emperor honorary titles with this epithet. ${ }^{80}$ All this information appears in the chapter

75 The Chinese words mi, sha and hua can refer to the Persian word mai and Arabo-Persian words sharāb and khamr for wine. Also see Zhu fan zhi, Hirth and Rockhill, 126, n. 4; Fujita Toyohachi, Zhongguo Nanhai, 220.

76 Qingbo zazhi: Qingbo biezhi, juan zhong 141, 142.

77 For the name, see Zhu fan zhi, Hirth and Rockhill, 127, n. 4.

78 Baoshun langjiang, laudatory title conferred on friendly alien military chiefs. Charles $\mathrm{O}$. Hucker, A Dictionary of Official Titles in Imperial China (Stanford University Press, 1985), 369 .

79 Xu zizhi tongjian changbian, 225: 5469; 313: 7592; 332: 7998; 333: 8017.

8o Song shi, 490: 14108, 14117 . 
on Cengtan in the official history of the Song dynasty. However, Chinese chroniclers of the Mongols, who compiled it, recorded only two delegations from Cengtan in 1071 and $1083 .{ }^{81}$ Song huiyao jigao records also confirm that Cengtan was a part of the Islamic world. ${ }^{82}$

The information about the ruler and his dynasty that ruled "for five hundred years and ten generations" refers to the "Abbasid Caliphs, a religious leader of the Islamic world. The similar records can be also found in Zhu fan $z h i$, which was compiled in 1225, referring to the 'Abbasid Caliphs in the chapter devoted to Baghdad: "the king is a direct successor of Fo Maxiawu (Buddha Muhammad) and the throne has, down to the present time, been transmitted through twenty-nine generations, covering a period of from six to seven hundred years." 83 When the Cengtan envoy arrived in China in 1071, the 'Abbasid Caliph was al-Qa'im and calculating the number of generations between the period of prophet Muhammad and Caliph al-Qa'im, we can count about "five hundred years and ten generations."

It can be concluded that according to the Song sources, Cengtan was located in the Islamic world and had not sent official missions to China before the Song period. The maritime road from Cengtan to Guangzhou passed via the port cities in Oman, South India and Sumatra, which may confirm that the itinerary was started in the Persian Gulf. Bielenstein assumed that Wuxun was located in the south of present-day Vietnam based on information that appeared in the entry on Champa in Wenxian tongkao. ${ }^{84}$ However, according to Wenxian tongkao Wuxun was one of the states at sea (hai shang) that arrived at the Chinese court together with Champa in 1011. The text says nothing about the location of Wuxun near Champa and cannot be placed in Vietnam..$^{85}$ The location of Wuxun near Champa can also be rejected by the itinerary between Cengtan and Guangzhou recorded in Song sources. It would be illogical for any mission arriving to China from the west to go first to Champa and then return to Kollam and Srivijaya before reaching Guangzhou. Moreover, Wuxun was recorded as a polity located in the Islamic world in Song sources. ${ }^{86}$

\footnotetext{
81 Song shi, 490: 14122-14123.

82 Song huiyao jigao, Fanyi 4: 92, 7:36.

83 王乃佛麻霞勿直下子孙, 相袭传位, 至今二十九代, 经六、七百年。 $Z u f a n$ $z h i$, 19. According to Hirth Muslim travelers who supplied this information cannot have ignored the Caliphs, who ruled before the 'Abbasids. For the English translation and the note regarding the calculating the number of generations, see Zhu fan zhi, trans. Hirth and Rockhill, 135-136, n.2.

84 Bielenstein, Diplomacy and Trade, 10.

85 Wenxian tongkao, 332: 2609-2.

86 Song shi, 490: 14121; Song huiyao jigao, Fanyi 4: 92, 7: 32.
} 
The same maritime roads between the Persian Gulf and China were recorded by Muslim authors of the ninth-twelfth centuries. For instance, al-Bīrūnī mentioned a story about a sailor called Māfannā from the port city Siraf in the Persian Gulf, who lived shortly before his time and traveled from Siraf to Khānfū (Guangzhou), the main seaport of China (al-Ṣinn). ${ }^{87}$ Marwazì describing Guangzhou stated that the majority of Persian and Arab merchants, who traveled there on their ships, were the Persians from Siraf and Arabs from Basra. The goods imported to Guangzhou were elephant tusk, pepper, asafoetida, glass, lapis lazuli, saffron, steel, tamarisk wood, walnuts, and all kinds of dried fruit, such as dates and raisins. He also added that the most appreciated thing imported to Guangzhou was khutū (rhino horn or walrus tusk), known in Chinese as bishān. ${ }^{88}$ Besides al-Muqaddasī stated that 'Aden, a port city in Yemen as well as Sohar in Oman were the passages (dahlïz) to China (al-Sịn). ${ }^{89}$ Mas'ūdī provided the itinerary of a merchant from Samarqand, who traveled from Basra to Guangzhou. The interesting fact is that his road exactly repeats the passage and the stages of the Cengtan delegation:

It is related that a merchant of the town of Samarqand in Transoxiana went from his home with a good stock of wares to Iraq, where he bought many goods of this country and proceded to Basra. He went by sea to Oman, ${ }^{90}$ whence he directed his voyage to Kalla [Kollam], which is half way to China, or about that. It is at present the commercial mart of the Muslim vessels of Siraf and Oman, where they meet with the merchants of China, who come to this island in their own vessels. In most ancient times it was different; for the Chinese vessels used to come to Oman, Siraf, to the coasts of Pars, and Bahrein, and al-Ubulla, and Basra and in the same way the vessels went from the ports mentioned as far as China. But since justice was no longer practised, and under the depraved state the government which we have described, both parties meet halfway. The aforementioned merchant went to Kollam on board a Chinese vessel which brought him into the sea-port of Khānfū [Guangzhou]. ${ }^{91}$

87 Kitāb taḥdìd nihāyāt al-amākin li-taṣhịh masāfāt al-masākin, trans. Bulgakov, 88-89, for the identification of Khānfū with Guangzhou (Canton), see 278, n. 9 o.

88 Tabä’’ al-hayawān, ed. and trans. Minorsky, 22. Elephant tusk, rhino horn as well as drugs and fruits mentioned by Marwazì were also recorded in the list of the Cengtan products.

89 Kitāb aḥsān al-taqāsìm fìma'rifat al-aqā lìm, ed. Goeje, 34. Also see the English translation Kitāb ahsān al-taqāsīm fì ma'rifat al-aqālèm, trans. Collins, 49.

9o According to Ibn Khurdādhbih Oman is the same as Sohar. Kitābal-masālikwa al-mamālik, trans. Velikhanova, 76.

91 Murüjal-dhahab wa ma'ädin al-jawhar, ed. and trans. de Meynard, vol. 1, 307-308; for the English translation, see Murüj al-dhahab wa maädin al-jawhar, trans. Sprenger, 328-329. I slightly modified the English translation based on the Arabic text. 
A detailed description of the sea route from the Persian Gulf to China with the stages in Oman, Kollam and Sumatra is also recorded by Ibn Khurdādhbih. ${ }^{92}$ George Hourani, following the information of times for the voyage to China given in Akhbär al-Sin wa al-Hind that was compiled in 851, stated that the voyage from Masqat (Oman) to Guangzhou took 120 days, excluding stops. ${ }^{93}$ The road from Cengtan to Guangzhou took 16o days "traveling day and night with a favorable wind." If we exclude the distance between Cengtan and Oman ${ }^{94}$ then it is almost the same duration. It should be pointed out that these durations are estimated by medieval Muslim and Chinese authors excluding stops and based on optimal weather and climate conditions. The real duration of the voyage from the major port cities in the Persian Gulf to China with the stops for trade in Oman, India and Sumatra could be much longer and the round trip might take about a year and a half. ${ }^{95}$

The interesting part of the passage on Cengtan is the use of elephants in logistics. Elephants are normally associated with sub-Saharan Africa, India, and Southeast Asia. However, the use of elephants in warfare and logistics was not unique or entirely unknown in Iran and Central Asia. Elephants were deployed, for instance, during the Sassanid dynasty, which procured these animals from their Indian allies. ${ }^{96}$ The most famous dynasty in the Islamic world that extensively used elephants in military affairs and made them symbols of power and authority were the Ghaznavids. Among this Turkic dynasty, the possession of elephants was a royal privilege; however, elephants could be granted to Amirs in some circumstances or used as diplomatic gifts to allied rulers. For instance, the Ghaznavid historian al-'Utbī in his Kitāb al-Yamin̄ì mentions war elephants in the list of gifts presented by Sultan Mahmud to Yusuf Qadir Khan. ${ }^{97}$ The presence of elephants in the Qarakhanid army is stated in Chinese sources, too. The Khotan ambassador who arrived at the court of Emperor Taizu of Song in 971 reported their victory over the Qarakhanids and the capture of one dancing elephant. ${ }^{98}$ According to Juwaynīs Ta'rïkh-i Jahāngushā, Indian elephants were even used in the army of the Qara Khitai, who gained them

92 Kitāb al-masālik wa al-mamālik, trans. Velikhanova, 77-83.

93 George F. Hourani, Arab Seafaring in the Indian Ocean in Ancient and Medieval Times (Princeton: Princeton University Press, 1995), 74.

94 According to Wenchang zalu, the road between Cengtan and Sohar took 20 days, see Wenchang zalu, 1: 3 .

95 Hourani, Arab Seafaring, 74-75.

96 For elephants in the Sassanian army, see Melville B. Charles, "The Rise of the Sassanian Elephant Corps: Elephants and the Later Roman Empire," Iranica Antiqua 42, (2007): $301-46$.

97 Kitāb al-Yamin̄i, trans. Reynolds, 316.

98 Song shi, 490: 14107. 
in the battle with the Ghurids (1186-1215) and brought them to Balasaghun. ${ }^{99}$ The Saljuqs also could receive elephants as diplomatic gifts during peace negotiations or obtained them during the war with the Ghaznavids. After the Saljuq conquest of Baghdad, when Sultan Toghrul Beg arrived in the city to have an audience with the Caliph in $1057-58$, the Caliph sent his people to meet Toghrul Beg and he was accompanied by his intimates, some in boats and some mounted on elephants. ${ }^{100}$ Moreover, the Saljuq ruling elite was depicted on horses, camels and elephants on mina $\bar{\imath} \bar{\iota}$ ware and pottery figurines found in Iran. ${ }^{101}$ Mas ūdī also mentioned the use of elephants in official ceremonies at the 'Abbasid court in Baghdad. ${ }^{102}$

Chinese authors often recorded commodities brought from foreign places as local products of those regions if they were widely used or traded there. However, these products could be also often imported from other countries and transferred further to China. The same applies to elephants. Certainly, elephants were not so common but represented power and prestige in the Turko-Islamic world at that period. Therefore, the Saljuqs often depicted elephants in their artworks and their envoys at the Chinese court could also point out the usage of elephants in their realm.

Most of the products of Cengtan were widely traded in the Islamic world and brought to China via the maritime routes. The existence of rhinoceros or rhino horns in the list of products may also lead the reader to Africa or Southeast Asia. However, according to records of medieval travelers and visual sources, rhinoceros were found in the Indus Valley and across the mountains of present-day Afghanistan at least until the sixteenth century. ${ }^{103}$ Moreover, Cengtan missions passed through Sumatra and they could transport rhino horns from there to China. Rice is also mainly associated with China, South and

99 Tảrīkh-i Jahāngushā, trans. Boyle, 360.

100 Mirāat al-zamān fì tärīkh al-a yàn, ed. Sevim, 25.

101 For instance, see Bowl Depicting a Lady Riding an Elephant, Iran, Saljuq period, retrieved from Minneapolis Institute of Art, bequest of Alfred F. Pillsbury, no. 50.46.434, https:// collections.artsmia.org/art/1096/bowl-depicting-a-lady-riding-an-elephant-iran; Elephant with howdah and figure, stonepaste, Iran, Saljuq period, retrieved from Freer Gallery of Art, Smithsonian Institution, Washington, D.C., Charles Lang Freer Endowment, F1967.26, https://asia.si.edu/object/F1967.26/; Elephant Carrying Two Figures Seated on Hawda and Mahout Seated on Neck, stonepaste, Iran, Saljuq period, retrieved from Metropolitan Museum of Art, no. 65.109.1, https://www.metmuseum.org/art/collection/search/ 451803 ? exhibitionId=\%7 Bfff5o63f $-8917-4243-83$ fo-o694of 436 c91\% $\%$ D\&oid $=451803$.

102 Murūj al-dhahab wa måădin al-jawhar, ed. and trans. de Meynard, vol. 8, 169 .

103 For the discussion of historical records, artifacts and paintings, including Babur on a rhinoceros hunt, see Leendert C. Rookmaaker, "Records of the Rhinoceros in Pakistan and Afghanistan," Pakistan Journal of Zoology 32, no. 1 (2000): 65-74. 
Southeast Asia. At the same time, rice was introduced to Central Asia already during the Kushan period and became an important culinary aspect of the culture in Central Asia and Iran by the Islamic era. ${ }^{104}$ It should be pointed out that the Persian Gulf was famous for its many pearl fisheries. Idrīis recorded that there were about three hundred renowned places in the Persian Gulf where pearls were fished and these fisheries were richer and more productive than in India and Yemen. ${ }^{105}$ The main centers of glass and wine production of the Islamic world were located in Iran. Wine has been always a traditional symbol of Persian culture. For instance, Shiraz was known as the center of the best wine-producing region in the pre-modern world. ${ }^{106}$ It should be also pointed out that the Cengtan missions stopped in the port cities of Oman, South India, and Sumatra, and could bring different commodities from these places that were viewed as local products of Cengtan at the Chinese court.

Another fact that may connect Cengtan with the Saljuq Empire is information about the coinage. According to the text, Cengtan used billon coins minted by the state. Saljuq dinars were not struck according to a standard. They had to be weighed, rather than counted. Moreover, in the eleventh century eastern Saljuq mints issued a debased composition with a low gold content and a mostly silver alloy. This practice was first initiated by Sultan Mahmud of Ghazna and then continued by the Saljuqs in the region. ${ }^{107}$

The location of Cengtan was discussed in Wenchang zalu in more detail and may lead towards the Persian Gulf rather than to Zanzibar:

主客所掌諸番[...] 南方十有五:[…] 其十三曰層檀, 東至海, 西至胡 盧没國, 南至霞勿檀國, 北至利吉蠻國。其十四曰勿巡, 舟船顺风泛 海，二十昼夜至层檀。108

104 For the recent archaeological report on rice agriculture in Uzbekistan during the Kushan period published by the joint Uzbekistan-Chinese mission, see Chen Guanhan et al., "Kushan Period Rice in the Amu Darya Basin: Evidence for Prehistoric Exchange along the Southern Himalaya," Science China Earth Sciences 63 (2020): 841-851. For the history of rice in Iran, see Marcel Bazin et al., "Berenj "Rice"," Encyclopcedia Iranica, ed. Ehsan Yarshater (New York: Encyclopædia Iranica Foundation, 1989), IV/2, 147-163, https:// iranicaonline.org/articles/berenj-rice.

105 Nuzhat al-mushtāq fì ikhtirāq al-āfäq, trans. Jaubert, vol. I, 375.

106 Jancis Robinson ed., The Oxford Companion to Wine (Oxford: Oxford University Press, 2006), 512-513.

107 For some examples of the Saljuq pale gold dinars, see Sheila R. Canby et al., eds., Court and Cosmos: The Great Age of the Saljuqs, New York: Metropolitan Museum of Art, 2016, $51-53$.

108 Wenchang zalu, 1:3. 
The Bureau of Receptions is in charge of all foreigners [...] There are fifteen states in the south: [...] The thirteenth one is called Cengtan; in the east it reaches the sea, in the west it reaches the Hulumo [or Hulumei] state, in the south it reaches the Xiawutan state, in the north it reaches the Lijiman state. The fourteenth one is called Wuxun; if one sails the sea on a ship or boat with a favorable wind, one will reach Cengtan in 20 days and nights.

All the place names mentioned in this passage are unknown and do not appear in any other sources, except for Wuxun, which refers to Mazun, a Persian name of Sohar, ${ }^{109}$ an important trade port between the Islamic world and China. This means that Cengtan was not located too far away from the main port cities of Oman. Therefore, Cengtan cannot be identified with Zanzibar. The sea that was located in the east of the Cengtan state is probably the Caspian Sea, but it could also refer to the Persian Gulf, or even to the more remote South China Sea.

Recently, Lu Yun, following Fujita Toyohachi, suggested that the term Hulumo (LMC. xhuă-luă-mut) should be derived from the word "Hurum," which was an Armenian word for Rome and refers to Byzantium. ${ }^{110}$ However, if Cengtan refers to the Saljuqs, it seems unlikely that the Saljuq ambassadors used this name instead of the Persian term Rum for Rome, which also applied to former Byzantine territories conquered by the Saljuqs. I contend that this word should be read as "Rum of the $h u$ people." The first part of this name, $h u$, meaning "barbarian," was a general term for foreign peoples living north and northwest of China and was mainly associated with peoples speaking Turkic, Mongolian, and Tungusic languages. However, it could also sometimes refer to other peoples of the Western Regions, like Tokharians or Sogdians. During the Song period, this term was also used referring to Central Asia, particularly in the context of products imported from this region. The second part of this term, Lumo (LMC. luă-mut), is very similar to the Chinese name Lumei (LMC. luǎ-mi) for Rum that was used by the Southern Song official Zhao Rugua in his records on foreign countries. ${ }^{111}$ Cengtan sent three envoys to China in 1071, 1081 and 1083 according to the Song sources. ${ }^{112}$ All of them were sent after the battle of Manzikert when the Saljuqs began to occupy Anatolia, the territories

\footnotetext{
109 Fujita Toyohachi, Zhongguo Nanhai, 220; Chen et al., Gudai Nanhai diming huishi, II, 999.

110 Lu, "Songdai Cengtan," 30; Fujita Toyohachi, Zhongguo Nanhai, 222-223.

111 Zhu fan zhi, 116-117; for the English translation, see Zhu fan zhi, trans. Hirth and Rockhill, 141-142.

112 Xu zizhi tongjian changbian, 313: 7592; 33: 7998; 333: 8017.
} 
known in the Islamic world as Rum. However, despite their conquest of this region, the Sultans of the Saljuq Empire never styled themselves as rulers of Rum; although it was common practice to include the names of the different countries that they conquered in their titles, Rum never appeared among them. ${ }^{113}$ For instance, the Saljuq Sultanate of Anatolia was viewed as a subordinate state of the Saljuq Empire until 1084. ${ }^{114}$ At the same time, Malik Shah was mentioned as the owner of Khurasan, Transoxiana, Kashghar, Balasaghun, Khwarazm, Nimruz, Iraq, Pars, Syria, Azerbaijan, Armenia, Arran, Antioch and Jerusalem. ${ }^{115}$ Rum was not in this list. Therefore, the ambassadors who came to the court of the Chinese emperor might refer to their subjects, the Saljuqs of Rum, as their western neighbors.

Fujita Toyohachi assumed that the southern neighbor of the Cengtan state Xiawutan (LMC. xhja:- vut-than) should refer to Hamadan. ${ }^{116}$ However, Hamadan was a part of the Saljuq Empire and could not be recorded as a neighbor state of Cengtan. Lu Yun suggested that Xiawutan may refer to the Ghaznavids. ${ }^{117}$ When the Cengtan ambassadors arrived in China, the Ghaznavids and the Saljuqs had signed a peace agreement initiated by the Ghaznavid ruler Ibrahim ibn Mas'ud (1059-1099), which stopped the further Saljuq conquest of the Ghaznavid territories. It was a time of cultural and social interaction via marriage alliances between the two dynasties. The Ghaznavids were strong enough in many ways to deal with the Saljuqs on equal footing. ${ }^{118}$ It was a time of cultural and social interaction via marriage alliances between the two dynasties.

The Lijiman (LMC. li'-kjit-ma:n) country, which was located in the north of Cengtan, according to Lu Yun, can refer to the western Qarakhanids. He attempted to read Liji as a Chinese word for the Turkic title Ilig. ${ }^{119}$ Ilig was the highest title of the Qarakhanids after the supreme title Khagan. Muslim authors often applied this name to the Qarakhanids. ${ }^{120}$ Thus, Lijiman may be a corrupt version of Ilig Khan or Ilig Turkman. ${ }^{121}$ The realm of the western

\footnotetext{
113 Dimitri Korobeinikov, "The King of the East," 71.

114 Ibid, 72.

115 Siyāsatnāma, trans. Darke, 170.

116 Fujita Toyohachi, Zhongguo Nanhai, 222-223.

117 Lu, "Songdai Cengtan," 30.

118 Bosworth, "Ghaznavids," $578-583$.

119 Lu, "Songdai Cengtan," 31.

120 For instance, see Saljūqnāma, ed. Bosworth and trans. Luther, 29-30; Kitāb al-Yamīnī, trans. Reynolds, $315^{-318 .}$

121 It should be noted that terms "Turk" and "Turkman" were to some extent interchangeable in Muslim sources at least until the end of the thirteenth century. The difference between the terms did not depend on their language or ethnic divisions. The term "Turk" was
} 
Qarakhanids was viewed in China as a part of the Islamic world, and the western Qarakhanids as Muslims (Dashi). I could not find any other name in Chinese sources that refers to the western Qarakhanids, except Puhualuo (Bukhara), which is mentioned in the list of the Muslim states recorded by the Southern Song official Zhao Rugua. ${ }^{122}$ However, during that period, the Saljuq Sultans established close relative links through marriage alliances not only with the Ghaznavid Sultan, but also with the Qarakhanids, which went on until the times of Sultan Sanjar. Therefore, if Cengtan is the Saljuq Empire then Lijiman and Xiawutan should most likely refer to the western Qarakhanids and the Ghaznavids, as the neighboring territories of the Saljuq Sultans in the north and the south.

Song sources also depicted a mission dispatched from "Muslim Tabriz" (Dashi Tuopoli) in $1073 .{ }^{123}$ Tabriz that was a center of the Rawadid dynasty had been incorporated into the Saljuq Empire by this time. The envoy from Tabriz $\mathrm{Pu}$ Tuopolici (Abu Tabrizi?) ${ }^{124}$ had the Chinese title baoshun langjiang. This mission was probably organized by the Saljuq regional ruler and for this reason distinguished from Cengtan.

The envoys from Cengtan were sent to China during the rule of Alp Arslan (1063-1072) and his son Malik Shah I, the most prosperous period of the Saljuq Empire. They greatly expanded the empire's territory and consolidated their power from Khurasan to Jerusalem, defeating rivals to the south and northwest. Therefore, it seems that the Saljuq Sultans sought to have direct diplomatic contacts with China, which, despite the silver crisis of the eleventh-twelfth centuries, paid pure silver for commodities from the Islamic world. Malik Shah I was well known in Song China: his name was even applied to the Saljuq territories in the description of Anatolia, where the territories of Mielisha (LMC. mjiat-ližk-sa:) were depicted as the southeastern neighbors of

used referring to both the sedentary and nomadic groups, while Turkmans were mostly nomads. Dimitri Korobeinikov, Byzantium and the Turks in the Thirteenth Century (Oxford University Press, 2014), 3-4.

122 Zhu fan zhi, Hirth and Rockhill, 116-117. Zhao Rugua started this work in 1190 and completed it in 1225. The Khwarazmshahs defeated the Qarakhanids in 1210 and Bukhara became one of the residences of the Khwarazmshah. However, the author could have obtained information on the territories long before these events, when Bukhara was one of the main cities of the western Qarakhanids.

123 Xu zizhi tongjian changbian, 246: 5977; Song huiyao jigao, Fanyi 7: 33; 4: 92. For the identification of Tuopoli or Tuopolici with Tabriz, see Chen et al., Gudai Nanhai diming huishi, II, 1053 .

124 For the Chinese "Pu" as a transliteration for Arabic "Abu," see Chaffee, The Muslim Merchants of Premodern China, 59-61. 
the Saljuq Sultanate of Rum. ${ }^{125}$ It should be pointed out that the missions from Cengtan had been sent via the maritime road before the Malik Shah's conquest of the Qarakhanid territories. Chinese sources recorded missions from the Dashi realm that arrived jointly with Qarakhanid delegations via land roads. ${ }^{126}$ These missions could be also dispatched by the Saljuqs, when the Qarakhanids submitted to Malik Shah.

Brief information about the Saljuqs also appeared in Liao shi, in the description of the Qatwan battle between the Saljuq Sultan Sanjar and the Qara Khitai Gurkhan Yelü Dashi in 1141 near Samarqand (Xunsigan). The Saljuq Empire was called Huershan (Khurasan) of the Western Regions. ${ }^{127}$ Before his reign, Sultan Sanjar was a governor (Malik) of Khurasan from 1096, appointed by his halfbrother Barkyaruq (1094-1105).

Chinese sources often applied different names to the same polity. The Saljuq Empire was generally known as Dashi. The official missions dispatched via maritime roads from the Saljuq Sultans Alp Arslan and Malik Shah were depicted under the term Cengtan. Later, when the Saljuqs established their rule at the Qarakhanid realm, the polity was also known under the name of Sultan Malik Shah (Mielisha).

The identification of Cengtan with the Saljuq Empire remains open for further discussion. However, according to the Chinese text it is known that Cengtan was a part of the Islamic world and located not far from the Gulf of Oman. It should be also pointed out that there were not so many polities in the region during the second half of the eleventh century would have had all products and commodities mentioned in the Cengtan entry at their disposal and been capable of dispatching ships to China.

\subsection{Envoys from Fulin: The Byzantines or the Saljuqs of Anatolia}

Chinese sources applied different names to Anatolia under the Saljuq Sultanate of Rum: Fulin, ${ }^{128}$ Meilugudun ${ }^{129}$ and Lumei. ${ }^{130}$ Fulin, which is most likely derived from Middle Persian Hrwm (Rome), originally referred to the Byzantine

\footnotetext{
125 Xu zizhi tongjian changbian, 317: 7661; Song shi, 490: 14124.

126 Song shi, 18: 345; 490: 14109; Xu zizhi tongjian changbian, 300: 7310; Song huiyao jigao, Fanyi 7: 42.

127 Liao shi, 30: 356. Liao shi mentioned Huershan as a name for the coalition of the Western Region's states. However, it is clear that it refers to Khurasan.

128 Xu zizhi tongjian changbian, 317: 7661-7662; Song shi, 490: 14124-14125.

129 Lingwai daida, 3: 54; for the German translation, see Lingwai daida, trans. Netolitzky, 46.

130 Zhu fan zhi, 20; for the English translation, see Zhu fan zhi, trans. Hirth and Rockhill, 141-142.
} 
Empire in official Tang sources. ${ }^{131}$ The description of Fulin in Song sources differs from the Tang accounts and refers to the new polity in Asia Minor. ${ }^{132}$ Lumei comes from the term Rum, which referred to the Byzantine Empire in the medieval Islamic world. The Saljuqs called the lands of their sultanate as Rum because it had been established on territory long considered "Roman" in the Islamic world. Meilugudun was identified by Hirth as the Saljuq Sultanate of Rum. ${ }^{133}$ However, he also suggested that it could be a Chinese transcription of the Arabic word mulhidün, meaning "infidels" or "heretics," and referring to Constantinople. Furthermore, he assumed that it could be a composite picture of the remote Mediterranean region in China. ${ }^{134}$ However, the Qur'an uses the term mulhidün mainly for non-believers and does not apply to Christians. I suggest that Meilugudun (LMC. mi-luǎ'-kut-tun) probably derives from the designation "mulk-i Rūm," meaning "the kingdom of Rum" and refers to the entire territory of the Saljuq Sultanate of Rum.

The term Fulin was used by court historians in official Chinese histories, while Lumei and Meilugudun appeared in records of foreign countries that were written by officials who served in border regions and relied mainly on information that they obtained from foreign merchants. It seems that court historians preferred to use the familiar term for the region, while other authors applied the name, which was in use among the Saljuqs themselves and in the entire Islamic world.

The description of Fulin in Song shi ${ }^{135}$ is shorter than the account recorded in Xu zizhi tongjian changbian. It omitted important information that helps to identify Fulin with the Saljuqs of Rum rather than with the Byzantium. Therefore, the description of Fulin in Xu zizhi tongjian changbian can be applied in tracing the usage of this term during the Song period:

131 For the term Fulin and its origin during the Tang period, Samuel N.C. Lieu, "Epigrahica Nestoriana Serica," in Exegisti Monumenta. Festsschrift in Honour of Nicholas Sims-Williams, ed. Werner Sundermann, Almut Hintze, and Francois de Blois (Wiesbaden: Harrassowitz, 2009), 236-245.

132 For the term Fulin during the Song period, see Friedrich Hirth, "The Mystery of Fu-lin," Journal of the American Oriental Society 30, no. 1 (1909): 1-31. For a more recent overview of the issue, see Xu Jialing 徐家玲, "Baizhanting haishi Saierzhuren guojia? Xi Song shi, 'Fulin guo chuan' de yi duan jizai 拜占庭还是塞尔柱人国家? 析《宋史 - 拂棘国 传》的一段记载 [Byzantium or Saljuq Sultanate? On a piece of Narrative on "Fulin" in History of Song Dynasty]," Gudai wenming 古代文明 3, no. 4 (2009): 63-67; Duturaeva, "Cengtan and Fulin," 29-48.

133 Zhu fan zhi, trans. Hirth and Rockhill, 141-142.

134 Ibid, 142.

135 Song shi, 490: 14124-14125. 
元豐四年, 拂菻國貢方物, 大首領儞廝都令廝孟判言, 其國東南至滅 力沙, 北至大海, 四十程。又東至西大石及於閴王所居新福州, 次至 舊於闐, 次至灼昌城, 乃於闐界, 次東至黃頭回紀, 又東至達靼, 次 至種榅, 又至董邅所居, 次至林檎城, 又東至青唐, 乃至中國王界; 西至大海約三十程。其名滅力伊靈改撤, 國地甚寒, 王服紅黃衣, 以 金線織絲布纏頭, 每歲遇三月入佛寺燒香, 坐紅床, 人舁之。首領皆 如王之服, 或青綠、緋白、粉紅、褐紫, 亦各纏頭跨馬。城市田野各 有首領主之。每歲惟夏秋兩得俸, 給金、銀、綿、錦、穀、帛, 以治 事大小為差。刑罪輕者杖五七十, 重者一二百, 大罪盛以毛囊投之 海。土屋無瓦。產金、銀、珠、綿、錦、牛、羊、馬、獨槵駝、杏、 梨、糖、千年霜、巴欖子、大小麥、粟、麻, 以蒲桃釀酒。音樂彈胡 琴、筮篌, 吹小䇤策, 擊偏鼓, 唱歌拍手戲舞。不務戰鬥, 事小止 以文字往來詰問, 事大亦出兵。以金銀為錢, 無穿孔, 面鏊彌勒佛 名, 背鏊國王名, 禁私造。其言語與滅力沙同。至是貢鞍、馬、刀、 劍、珠。136

In the fourth year of the Yuanfeng era [1081], the Fulin state offered local products; main chieftain Nisidulingsimengpan said that in the south east his state reaches Mielisha [Malik Shah], in the north it reaches the Great Sea [the Black Sea], both are forty days of a journey. Also in the east it reaches western Dashi ${ }^{137}$ and Xinfuzhou ${ }^{138}$ resided by the king of Yutian [Khotan], ${ }^{139}$ next comes old Yutian, ${ }^{140}$ next comes the city of Zhuochang ${ }^{141}$ and then the borders of Yutian; next are the Huangtou Huihe [Yellow-Head Uyghurs], further in the east come the Dada [Tatars], and next come the Zhongwo [Chonghuls] ${ }^{142}$ and further come

136 Xu zizhi tongjian changbian, 317: 7661-7662.

137 The Western Qarakhanids.

${ }_{13} 8$ Xinfuzhou is the capital of the Khotan kingdom, which is modern Khotan.

139 The Eastern Qarakhanids.

140 Dividing the state of Khotan into new and old is unclear. I suppose that the new Khotan should be the entire territory of the eastern Qarakhanids centered in Balasaghun and Kashghar. The old Khotan refers to the previous territories of the Khotan kingdom, which was conquered by the Qarakhanids by the eleventh century and served as a residence for the Qarakhanid co-Kaghans.

141 Zhuochang is Yuechang, a city near present-day Cherchen or Qiemo county in Xinjiang.

142 ChonghulisaTurkic clannamestillinuse among the modernYogurs. ChristopherP.Atwood, "The First Mongol Contacts with the Tibetans," in Trails of the Tibetan Tradition:Papers for Elliot Sperling, ed. Roberto Vitali (Paris: UMR 8155 (CRCAO) of the French National Center for Scientific Research, 2015), 26. 
places resided by Dongzhan, next comes the city Linqin, ${ }^{143}$ further in the east comes Qingtang ${ }^{144}$ and then comes the boundaries of the kings of Zhongguo [China]; in the west it reaches the Great Sea, which is approximately thirty days' journey. The name of the king is Mieliyilinggaiche, the climate of the state is very cold, the king wears red-yellow clothes and a gold threaded silk turban; each year, when the third month comes he enters the temple of the Buddha to burn incense, he sits on a red bed and people carry him. ${ }^{145}$ The chieftains all wear royal-like cloth, some greenblue, [some] dark red, [some] white, [some] soft red, [some] brown and violet, as well as turbans, and ride horses. Each fortified city and province has its own chieftain who is in charge of it. ${ }^{146}$ They receive an official salary twice every year in summer and autumn, they are given gold, silver, cotton, brocade, grain, and silk, which differs according to the degree of seniority of their service. Minor offenses are punished with fifty to seventy strokes, more serious crimes with one to two hundred strokes, and major crimes are punished by throwing the accused into the sea in a sack. ${ }^{147}$ Local houses are without tiles. They produce gold, silver, pearls, silk floss, brocade, cattle, sheep, horses, dromedaries, apricots, pears, sweets, dates, almonds, various kinds of wheat, millet, sesame, and wine made from grapes. For music, they play huqin [fiddle],148 konghou [harp],

143 The exact location of this city is unclear. It was most likely a territory of Tsongkha in the Qinghai region. It probably refers to the present-day Dulan, which was one of the main cities along the Qinghai Road during the Tibetan Empire. For more details on Dulan and the Qinghai Road, see Makiko Onishi and Asanobu Kitamoto, "A Lesser Known Route: the Qinghai Route," In Silk Road in Rare Books: Narratives on Cultural Heritage along Silk Road with Figures and Photographs from Rare Books, Digital Silk Road Project, National Institute of Informatics, http://dsr.nii.ac.jp/rarebook/o7/, Japanese edition 2005, English revised edition 2010.

144 Qingtang is a place near present-day Xining that belonged to the Tsongkha confederation.

145 The visit of the ruler of Fulin to the so-called temple (which is a mosque) in the third month of each year probably refers to the Mawlid, the birthday of the prophet Muhammad, which is celebrated in the third month in the Islamic calendar Rabi' al-awwal.

146 This refers to the $i q t \bar{a}$ ' practice.

147 This description seems to correspond with the Romano-Byzantine punishment of poena cullei (from Latin "penalty of the sack"). It is likely that Byzantine law influenced Saljuq jurisprudence. For the solid Greek influence in the Sultanate, see Dimitri Korobeinikov, Byzantium and the Turks, 289-297. This punishment was also adopted by the Ottomans and mainly applied to women. This goes back to an old Turko-Mongol taboo on shedding women's blood. Rudolph Peters, Crime and Punishment in Islamic Law: Theory and Practice from the sixteenth to the twenty-first century (Cambridge: Cambridge University Press, 2005), 101.

148 Huqin is a generic term for a Chinese fiddle, literally 'barbarian string instrument'. The instruments are held vertically on the player's lap, and their music is marked by slides 
bili [small zurna] ${ }^{149}$ and one-sided piangu [drum]; they sing songs, clap hands and dance. They do not engage in military confrontations; if the matter is small, they try to ask about it only by written contacts and if the matter is significant, they also dispatch troops. They mint gold and silver coins; they have no holes, on the obverse is engraved the name of Milefo, ${ }^{150}$ and on the reverse there is the name of the king of the state. Private minting of coins is prohibited. The language they speak is similar to the language of Mielisha [Malik Shah]. As tribute they offer saddles, horses, knives, swords and pearls.

The entry on Fulin has an interesting commentary from Fulin zhengzhuan (Official Chronicle of Fulin) and added that according to this source, the Fulin state had not come to the Chinese court "for more than nine hundred years until today."151 There is no doubt that the information stating that this country did not send envoys in previous times applied to the new dynasty in Asia Minor, since Chinese sources recorded several embassies from Fulin during the Tang period, when this term was used for the Byzantine Empire. ${ }^{152}$ Therefore, the author of these words obviously meant the Saljuqs of Rum, who sent their envoy for the first time. Moreover, the dynastic histories of the Tang clearly stated that Fulin is ancient Daqin, the Chinese name for the Roman Empire,

and vibratos as the left hand moves freely along the strings. Typically, the horsehair of the bow passes between the strings and the arched wooden stick remains on the outside. The name huqin appears in China during the Song dynasty; however, this instrument apparently entered China from nomadic peoples centuries earlier.

149 Bili is a Chinese shawm, which is probably related to the Central Asian zurna.

150 Milefo is Maitreya, the Bodhisattva that will be the next to come after Shakyamuni Buddha (Siddhartha Guatama, the physical incarnation of the Buddha on Earth). As the term "Buddhist temple" ( fosi) in the text refers to an Islamic mosque, Maitreya may also represent the Caliph, a person considered a religious successor to the Islamic prophet Muhammad. It should be noted that prophet Muhammad was also mentioned as Buddha (Fo Maxiawu) in Song sources, Zhu fan zhi, 17, 19; for the English translation, see Zhu fan $z h i$, trans. Hirth and Rockhill, 124, 135. Therefore, Maitreya as a successor of Buddha may refer to the Caliphs who were religious successors of the prophet Muhammad. The Great Saljuqs as well as Sultans in Anatolia minted coins with the caliph's name on the obverse and the ruler's on the reverse, including a variation of the profession of faith (shahada). They carried uniform inscriptions which were used by all dynasties that recognized the 'Abbasid Caliphate. In the initial stage, the Saljuqs of Rum used the coinage of the Great Saljuqs and also Byzantine coins that were circulated at least in local markets. Later their coinage was separated from that of the Great Saljuqs. As far as I know, it was not earlier than the rule of Mas'ud I (1116-1155). Therefore, the description of Fulin coins may refer to dinars and dirhams of the Great Saljuqs.

${ }^{1} 5^{1}$ Xuzizhi tongjian changbian, 317: 7662.

$15^{2}$ Jiu Tang shu, 198: 5313-5315; Xin Tang shu, 221: 626o-6261. 
and descriptions of Fulin are passages copied from earlier sources. ${ }^{153}$ Song sources offer entirely new information that did not appear in previous eras and completely differs from the earlier descriptions of Fulin. This term was used as a geographical term during the Song period and applied to the Saljuq Sultanate of Rum.

There are some hypotheses regarding the name of the envoy and the ruler. Hirth assumed that the name Nisidulingsimengpan (LMC. ní-sz-tuă-liajy-

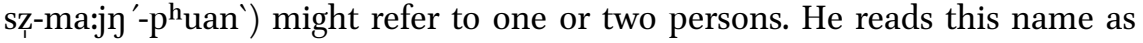
Nisidouling Simeng, which may stand for "Nestorius Simeon" or "Nestorius and Simeon." He did not consider the last character pan to be a part of the name and instead offered a meaning identical to ban, "in a company" or panguan "companion officer," "attaché." He assumed that governors Nestorius and Simeon could come in a company or the governor was accompanied by Nestorian Simeon. ${ }^{154}$ The Japanese scholar Kurakichi Shiratori suggested that Nisidu might be an official title of the envoy, which he could not identify, and Ling may stand for Rum. He assumed that the name of the envoy Simeng could be a Chinese transliteration of 'Uthman or Sulayman and pan may stand for the Turkic title Beg/Bey or Pasha. ${ }^{155}$ Yang Xianyi assumed that Nisidouling derives from the honorific noble title Maistre and Simengpan is Simon de Monfort. Yang Xianyi suggested that he could be appointed as ambassador by the Byzantine emperor. ${ }^{156}$ However, there is no historical record to confirm this assumption. It should be added that the title da shouling (main chieftain) was often applied to Turkic tribal leaders.

The name of the ruler was recorded as Mieliyilinggaiche (LMC. mjiat-liǎk?ji-liajn-kaj'-trhiat). The envoys from Fulin arrived at the Song court in 1081 and 1091. The rulers of the Saljuq Sultanate of Rum in this period were its founder Sulaiman ibn Qutulmish (1077-1086) and his relative Abu'l-Qasim (10861092). In Song shi it was given in a slightly different form, as Mieliyilinggaisa. ${ }^{157}$ Hirth suggested that Mieliyi is the name of Nicephorus Melissenus, who had

153 For descriptions of Fulin in the Tang sources, see Friedrich Hirth, China and the Roman Orient: Researches into their Ancient and Medieval Relations in Old Chinese Records (Shanghai \& Hong Kong: 1885, rpt. Chicago: Ares, 1975), 51-61; Donald D. Leslie, and Kenneth H.J. Gardiner, The Roman Empire in Chinese Sources (Roma: Bardi, 1996), 113, 281-282.

154 Hirth, "The Mystery of Fu-lin," 29-30.

155 Kurakichi Shiratori, 白鸟库吉, Saiwai shidi lunwen yicong 塞外史地论文译丛 [Translations of Research on History and Geography of the Regions Beyond the Great Wall] (Changsha: Shangpang yinshuguan, 1938-1939), 62.

156 Yang Xianyi 杨宪益, Yiyu oushi译余偶拾 [Occasional Collection made during the time remained after translation] (Beijing: Sanlian shudian, 1983), 213-214.

157 Song shi, 490: 14124. 
the title of the Byzantine emperor in this period; Ling is an imperfect attempt at the word Rum and Gaisa stand for the Greek "Kaisar" (Caesar). ${ }^{158}$ Shiratori assumed that Mieliyiling is the Saljuq title Malik al-Rüm ("King of Rum") and Gaisa is the Islamic title Ghāzi ("Warrior"). ${ }^{159}$ The Saljuq Sultan of Rum could be also introduced as a ruler of territories that once belonged to the Roman Emperor (Turk. Rüm Qaisar). Therefore, his name can be also read as Malik-i Rüm Qaisar ("King of the Roman Caesar"). Sulaiman ibn Qutulmish supported Nicephorus Melissenus, who received the title "Qaișar" in gaining the Byzantine throne, and Sulaiman, as his supporter, could emphasize it in his letter sent to China. At the same time, until the mid-twelfth century we have no reliable information on the royal titles of the Saljuqs of Rum with which we can confirm the existence of this title.

It should be pointed out that attempts to identify the names of the Fulin ruler and his envoy do not provide strong evidence on the origin of this mission. But the description of Fulin offers some crucial details that refer to the Saljuqs. For instance, the territories between Fulin and China illustrate that the envoy came to the Song court by land roads. Song shi confirms this information, stating that the Fulin delegations used overland roads to get to China despite the threat of the Khitans and Tanguts along the way. ${ }^{160}$ The envoy reported that they first arrived in the properties of the Saljuq Sultan Malik Shah (Mielisha) and then crossed the territories of the Qarakhanids (Xi Dashi). In Khotan they joined the Qarakhanid delegation, crossed Cherchen, places occupied by the Yellow-Head Uyghurs, Straw-Head Tatars and Chonghuls. Then they passed through the cities of the Tsongkha kingdom Linqin and Qingtang and arrived in Kaifeng. The Qarakhanid envoy also confirmed this itinerary. ${ }^{161}$ It would have been difficult and expensive for the Byzantines during the wars with the Saljuqs to organize the mission that had to cross the territories of the Saljuqs and also to negotiate with the Qarakhanids, who were the allies of the Saljuqs to get their support along the way to Tibet and China.

Song sources recorded another mission from Fulin that came to the Song court twice in $1091 .{ }^{162}$ I tried to find any mention of these missions from Rum in Muslim sources. The envoys passed through the territories of the Great Saljuqs and the Western Qarakhanids before they arrived in Khotan and traveled further to Tibet and China. In fact, Ibn al-Athīr recorded that in

\footnotetext{
158 Hirth, "The Mystery of Fu-lin," 25, 27-28.

159 Shiratori, Saiwai shidi, 61-62.

160 Song shi, 485: 13981.

161 Xu zizhi tongjian changbian, 335: 8061; 455: 10906. For the discussion of this road, also see, Chapter 3 .

162 Xu zizhi tongjian changbian, 455: 109o6; 457: 10943; 458: 11186.
} 
1089/109o an envoy from Malik al-Rüm arrived in Isfahan to offer fixed tribute (al-kharäj al-muqarrar) to Saljuq Sultan Malik Shah. The envoy accompanied Sultan Malik Shah during his military campaign in Transoxiana. They crossed the Amu Darya, conquered the cities of Bukhara and Samarqand, and when they reached Uzgend Malik Shah requested that the Qarakhanid Khagan in Kashghar submit to him. The Qarakhanid Khagan acknowledged his supremacy. The envoy was brought by Saljuq vizier Niẓām al-Mulk in order to show him the territories that belonged to Malik Shah, and when they reached Kashghar he allowed him to return to his country. He wanted the chronicles to record that the envoy from Malik al-Rüm brought tribute (jizya) to Sultan until the gate of Kashghar. ${ }^{163}$ This envoy from Rum probably went farther to the East accompanied by the Qarakhanid delegation and arrived at the Song court in 1091. Ibn al-Athīr did not provide details that could clarify the origin of this mission from Rum. At the same time, the Saljuqs of Rum were often depicted as Malik al-Rüm in Muslim sources. ${ }^{164}$ The Byzantine emperors were known as Qaișar-i Rüm. ${ }^{165}$ The author applied first the term kharāj and then jizya, referring to the taxes offered by the envoy. Kharäj was a type of Islamic land tax that was initially collected from conquered territories and non-Muslim subjects but later used as a general term to refer to any kind of taxes.Jizya also referred to a poll tax that was charged on non-Muslim subjects. The terms kharäj and jizya could be also used interchangeably. Obviously, this tax was collected from the Byzantine subjects of the Saljuqs.

Xu zizhi tongjian changbian recorded important information that was omitted in Song shi, which relates to the language of Fulin. It was pointed out that their language was similar to the language of the Saljuq Sultan Malik Shah. ${ }^{166}$ This means that descriptions of Fulin in Song dynasty sources refer to the Saljuq Sultanate of Rum and not to Byzantium. Moreover, Fulin ambassadors presented typical nomadic products at the Chinese court such as horses and swords. ${ }^{167}$ The image of the Fulin mission presenting horses and other commodities was depicted by Li Gonglin in his portrait of foreign envoys from ten countries Wanfang zhigong tu. ${ }^{168}$

The Qarakhanids accompanied the Saljuq missions from Rum to Tibet and China. They offered the same service to other diplomatic delegations from the

\footnotetext{
163 Al-Kämil fì al-ta'rīkh, ed. Tornberg vol. 10, 113; Al-Kämil fì al-ta'rīkh, trans. Bulgakov and Kamoliddin, 222-223.

164 Dimitri Korobeinikov, "The King of the East and the West, 79.

165 Siyāsatnāma, trans. Darke, 61, 79 .

166 The same information can be found in Song huiyao jigao, Fanyi 4: 19.

167 Xu zizhi tongjian changbian, 317: 7662.

168 For the image, see Figure 8.2.
} 
Islamic world. For instance, a mission from Dashi (Muslims) that arrived in the Chinese court in 1096 came together with the Qarakhanid delegation. ${ }^{169}$ This mission was probably sent by the Western Qarakhanids from central parts of Transoxiana or by the Great Saljuqs. The Qarakhanid Khagans also provided written documents for foreign delegations, which allowed them to travel from Turkistan to Tibet and China. Thus, in 1089 a mission from the ruler of the Miaoli state arrived at the Song court for the first time. The ambassadors Lingyi (Rūmī?) and Si Masumi (or Hui Masumi, Muslim Ma'ṣūmī?) provided documents from their ruler and the Qarakhanid Khagan, asking to treat them the same as Qarakhanid delegations and grant permission to trade. The request was approved by imperial edict. Moreover, the Miaoli envoy was also called banci like the Qarakhanid envoys. ${ }^{170}$

The role of banci in Song China included diplomatic, commercial and military service. ${ }^{171}$ It is not clear what kind of state was meant here. It was recorded that Miaoli was located in the west or more precisely in the southwest from Anatolia:

\section{拂菻國東至于闐西至邀黎 南至大石北至黑海 172}

In the east the Fulin state [the Saljuqs of Rum] reaches Yutian [the Qarakhanids of Khotan], in the west it reaches Miaoli, in the south it reaches Dashi [the 'Abbasids or the Great Saljuqs], in the north it reaches the Black Sea.

In the following description we find more ethnographical information:

邀黎國王都晛達州東至大食東南至西涼東北至拂菻民俗七日一次 禮佛173

In the east Miaodazhou, the capital of the king of the Miaoli state reaches Dashi [the 'Abbasids or the Great Saljuqs], in the southeast it reaches Xiliang [?], in the northeast it reaches Fulin [the Saljuqs of Rum]. According to the custom of people, they worship the Buddha once every seven days.

169 Song shi, 18: 345; Song huiyao jigao, Fanyi 7: 42.

170 Song shi, 489: 14087-14088; Xu Zizhi tongjian changbian, 429: 10357.

171 I give more details on the meaning of this term in Chapter 2.

172 Yueshu, 158: 14a.

173 Ibid, 157:15b. 
The expression lifo, literally translated as "worship the Buddha," does not necessarily mean that the people of Miaoli were Buddhists. It was a common practice among Chinese authors to use Buddhist expressions for other religions. For instance, the prophet Muhammad was also referred to as "Buddha" in Song sources. ${ }^{174}$ Here the last phrase refers to the jumu'ah a congregational prayer that Muslims hold every Friday. Taking into account the fact that the Miaoli ambassadors had Muslim names, it can be assumed that Miaoli was a part of the Islamic world. The geographical descriptions imply that this state was located somewhere in the west of Asia Minor, which can refer to a very broad area, including Northeast Africa.

The Qarakhanids evidently played a significant role in the Sino-Tibetan world: not only did their documents allow foreign delegations to travel to Tibet and China, they also enjoyed special treatment at the Chinese court. This means the Qarakhanids established themselves as intermediaries between the Islamic world and China.

TABLE 4 Missions to the Northern Song from the Saljuq territories

\begin{tabular}{|c|c|c|c|c|}
\hline & Name and date & Envoy & Gifts & Loans \\
\hline 1. & $\begin{array}{l}\text { Cengtan (Sultan) } \\
\text { July } 75,1071 \\
\text { (XZTC 225: } 5469 \\
\text { ss 490: } 14108,14117 \text { ) }\end{array}$ & unspecified & unspecified & unspecified \\
\hline 2. & $\begin{array}{l}\text { Tuopoli (Tabriz) } \\
1073 \\
\text { (XZTC 246: 5977; } \\
\text { SHY: FY 7: 33; 4: 92) }\end{array}$ & $\begin{array}{l}\text { baoshun langjiang } \\
\text { Pu Tuopolici } \\
\text { (Abu Tabrizi?) } \\
\text { and his son } \mathrm{Pu} \\
\text { Mamo } \\
\text { (Abu Mahmud?) }\end{array}$ & $\begin{array}{l}\text { Pearl, glass, golden } \\
\text { belts, beckets } \\
\text { and bridles, } \\
\text { beads, camphor, } \\
\text { frankincense, ivory, } \\
\text { dates, opaque glass } \\
\text { vessels, drugs }\end{array}$ & $\begin{array}{l}\text { Title langjiang } \\
\text { for Pu Mamo }\end{array}$ \\
\hline 3. & $\begin{array}{l}\text { Cengtan } \\
\text { July 31, 1081 } \\
\text { (XZTC 313: 7592; } \\
\text { SHY: FY 4: 92) }\end{array}$ & $\begin{array}{l}\text { baoshun langjiang } \\
\text { Cengjiani }\end{array}$ & unspecified & unspecified \\
\hline
\end{tabular}

174 Zhu fan zhi, trans. Hirth and Rockhill, 124. 
TABLE 4 Missions to the Northern Song from the Saljuq territories (cont.)

\begin{tabular}{|c|c|c|c|c|}
\hline & Name and date & Envoy & Gifts & Loans \\
\hline \multirow[t]{5}{*}{4.} & Fulin (Rum) & Main chieftain & local products & \\
\hline & November 9, 1081 & Nisidulinsimengpan & & \\
\hline & $($ XZTC 317: 7661 & & & \\
\hline & SS 16: 305; SHY: & & & \\
\hline & $F Y$ 4: 19) & & & \\
\hline \multirow[t]{5}{*}{5.} & Cengtan & unspecified & local products & 2000 liang \\
\hline & February 2,1083 & & & silver \\
\hline & (XZTC 332: 7998, & & & (February 26) \\
\hline & 333: 8o17; & & & \\
\hline & ss 490: 14108, 14117) & & & \\
\hline \multirow[t]{6}{*}{6.} & Fulin & unspecified & unspecified & 200 bolts of \\
\hline & 1091 & & & cloth, silver \\
\hline & (XZTC 457: 10943; & & & bottle, gar- \\
\hline & SHY: FY 4: 19) & & & ment, golden \\
\hline & & & & belt \\
\hline & & & & $(\text { May 10) })^{a}$ \\
\hline \multirow[t]{3}{*}{7 . } & Fulin & unspecified & unspecified & unspecified \\
\hline & February 1, 1092 & & & \\
\hline & (XZTC 468: 11186) & & & \\
\hline
\end{tabular}

a The arrival date of this envoy who received imperial gifts was not recorded.

\section{The "Uyghurs" of Khwarzm: Records on the Khwarazmshahs}

Khwarazm usually appears in chapters related to foreign countries in the Chinese official histories as a country located in the Western Regions. However, Khwarazm was not mentioned in the history of the Song and the Liao dynasties. Was this because the Khwarazmshahs did not send official delegations to the Song and the Liao courts, or perhaps because not all archival documents survived till the time when the Mongols compiled the official histories of the previous dynasties? Can we also assume that the Mongols decided to omit possible information about their main confronters in Central Asia? These questions remain open. Even if the Qarakhanids were able to provide the Khwarazmian market with Chinese goods, it is strange that the Khwarazmshahs did not attempt to send official envoys with the Qarakhanid assistance to China as the 
Saljuq Sultans did. Even the Ghaznavids sought to establish direct contact with China in the initial stage of their rule. The only Song documentation that may refer to possible contacts with Khwarazm is Zhu fan zhi written by the Song official Zhao Rugua. He provided a list of twenty-four Muslim countries. The country of Luoshimei in this list may be a corrupt transliteration of Khwarazm that represents the sound "razm."175

Chinese sources provide more information on the Khwarazmshahs within the events concerning the Khitan conquest of Samarqand and later the Mongol invasion in Central Asia. The first data on the Khwarazmshahs in Chinese accounts appeared in the description of the Qatwan battle between the Khitans and the Saljuqs in 1141. After the Jurchen invasion and the fall of the Liao dynasty in 1125, the Khitans, who once dominated in a vast area of Siberia and North China did not want to become subjects of the newly emerged dynasty of the Jurchens. Therefore, some Khitans decided to join a group headed by a representative of the imperial family Yelü Dashi and move towards Central Asia, where they founded the Westren Liao, or as it was known in Muslim sources, the Qara Khitai Empire. Yelü Dashi defeated the army of the Saljuq Sultan Sanjar in 1141 on the Qatwan steppe, near Samarqand and took the political dominance over the region into his hand. ${ }^{176}$ After his victory, Atsiz Khwarazmshah (1127-1156) arrived in Samarqand and submitted to Yelü Dashi. ${ }^{177}$ This event was described in Liao shi:

至尋思干, 西域諸國舉兵十萬, 號忽兒珊, 來拒戰。兩軍相望二里 許。諭將士曰:「彼軍雖多而無謀, 攻之, 則首尾不救, 我師必勝。 」遣六院司大王蕭斡里刺、招討副使耶律松山等將兵二千五百攻其 右; 樞密副使蕭刺阿不、招討使耶律术薛等將兵二千五百攻其左; 自 以眾攻其中。三軍俱進, 忽兒珊大敗, 僵屍數十里。駐軍尋思干凡九 十日，回回國王來降，貢方物。178

When he [Yelü Dashi] reached Xunsigan [Samarqand], all states of the Western Regions mobilized troops, numbering 100,00o men and called it Huershan [Khurasan], ${ }^{179}$ and arrived to resist an attack. The two armies

175 Zhu fan zhi, trans. Hirth and Rockhill, 116-117, 121, n. 12.

176 Al-Kämil fì al-ta'rükh, ed. Tornberg, vol. 11, 53-57; Al-Kämil fì al-ta'rükh, trans. Bulgakov and Kamoliddin, 241-247.

177 Țabaqāt-i Nāṣirī, trans. Raverty, 238-239; Tärükh-iJahān-gushāa, trans. Boyle, $35^{6}$.

178 Liao shi, 30: 356 .

179 Emil Bretschneider assumed that Huershan has some resemblance in sound with the title Khwarazmshah. But the Chinese authors obviously referred in this text to Sultan Sanjar, who was a ruler of Khurasan. Emil Bretschneider, Mediaeval Researches from Eastern 
faced each other from a distance of 2 li. He [Yelü Dashi] instructed his officers and men and said: "Although those troops are numerous, they do not have a strategy; if we attack them, then its head and tail will not come to the rescue and our army will certainly win." He dispatched a troop of 2,50o men commanded by the liuyuansi dawang [Great King of the Bureau of the Six Divisions] Xiao Wolila, the zhaotao fushi [Bandit-suppression Vice Commissioner] Yelü Songshan and others to attack them from the the right; he dispatched a troop of 2,500 men commanded by the shumi fushi [Military Affairs Vice Commissioner] Xiao Laabu, the zhaotaoshi [Bandit-suppression Commissioner] Yelü Shuxue to attack them from the left; [Yelü Dashi] himself with the crowd attacked them in the center. These three troops rushed together and Huershan suffered a crushing defeat and there were corpses on the ground for 10 li. The army was quartered in Xunsigan in total for ninety days, and the king of the Huihui state arrived with submission and presented local products.

Khwarazm was recorded in this text as Huihui, a term that applied during the Mongols to Central Asians and westerners in general. Huihui is considered to be a term meaning "Muslims," replacing the name Dashi, which was used from the Tang to the Song periods. But the Mongols also used this term referring to people of other religions. The origin of the term Huihui is unclear. It could derive from the name Huihe or Huigu used for the Uyghurs in Chinese sources before the Mongols. ${ }^{180}$ For instance, Khwarazm was recorded as "the Uyghur state" and Muhammad Khwarazmshah as "the ruler of the Uyghurs" in Chinese accounts compiled shortly after the Mongol conquest of Central Asia.

When Genghis Khan was in Central Asia, he also received foreign embassies from different places. One of these delegations was sent by the Jin Emperor Xuanzong (1213-1224). It was headed by Wugusun Zhongduan, who visited the Mongol court in Khurasan in 1220-1221. His journey was depicted by his friend Liu Qi (1203-1250), who compiled the travel book Bei shi ji (Records of the Northern Embassy). The author called Khwarazm and other territories Huihe guo (Uyghur state), which was probably a common name of Central Asia in China during this period. The region was probably associated with the Uyghurs due to the similar customs and traditions of Turkic peoples. Chinese

Asiatic Sources (London: Kegan Paul, Trench, Trübner \& Co., 1888), vol. 1, 215. For the name of Khwarazm in Chinese sources, see Ying Lin, "Some Chinese Sources on the Khazars and Khwarazm," Archivum Eurasiae Medii Aevi 11 (2000-2001): 339-64.

180 Liu Yingsheng, "A Lingua Franca along the Silk Road: Persian language in China between the 14th and the 16th centuries," in Aspects of the Maritime Silk Road:From the Persian Gulf to the East China Sea, ed. Ralph Kauz (Wiesbaden: Harrassowitz, 2010), 87. 
authors could also just follow names used among the Mongols, who appointed mostly Uyghurs to administrative positions and might have inspired the term "Uyghur" for Central Asians. Later this term in the form of Huihui started to be associated with western people in general during the Yuan and Ming dynasties. Huihui was also used to the Khanate of Khiva during the Qing dynasty $(1644-1912) .{ }^{181}$

The Jin ambassador described the peoples of Central Asia dividing them into main three groups. The first group was "Muslim Uyghurs" (Mosuluman Huihe), which most likely referred to the people who lived in the territory of the former Khwarazmshah Empire including Transoxiana. The second group was called "Herat Uyghurs" (Yili Huihe), which applied to the people of Khurasan. The third group was "Indian Uyghurs" (Yindu Huihe):

其人種類甚衆, 其須髡拳如毛, 而紃黄淺深不一。面惟見眼、鼻。其 嗜好亦異。有沒速魯巒回紇者, 性殘忍, 肉必手殺而噉, 雖齋亦酒 脯自若。有遺里諸回紅者, 頗柔懦, 不喜殺, 遇齋則不肉食。有印都 回紇者，色黑而性愿，其餘不可殫記。182

Their [Huihe] people have various kinds of physical types; their mustaches and beards are curly like wool and the blackness and yellowness of them are not the same in lightness and darkness. Only their eyes and noses are seen on their faces. Their addictions and hobbies are also different. There are the Mosuluman Huihe, by nature they are cruel and ruthless, they eat meat [of animals] that should be killed by their own hands, even during fasting they freely drink wine and eat dried meat. There are the Yili Huihe, they are quite weak and timid, they do not like to kill, if fasting comes no meat is eaten. There are the Indu Huihe, their faces are black and they are honest by nature, and the rest of them cannot be completely recorded.

The Jin envoy, on his road back to China near Talas, encountered the famous monk Chang Chun (1148-1227) who was traveling to the Mongol court. Their conversation was recorded by Li Zhichang (1193-1256), one of the disciples of the monk who accompanied him during the journey to the Western Regions

181 Qing shigao, 4: 100; 7: 244.

182 Gui qian zhi, 13: 167-169; for the English translation, see Emil Bretschneider, Notes on Chinese Mediaeval Travelers to the West (Shanghai: American Presbyterian Mission Press; London: Trübner \& Co., 1875), 100-107. 
and compiled a travelogue. ${ }^{183}$ The envoy said that he had left the Mongol court seven months and twelve days ago. He informed Chang Chun that Genghis Khan moved towards India to pursue "Sultan Khan" (Suanduan Han). ${ }^{184}$ Here the envoy meant the confrontation between Genghis Khan and Jalal al-Din Khwarazmshah.

Chang Chun and his disciples started their journey in North China and were dispatched from Beijing in February 1221. They reached Samarqand in December 1221, shortly after the fall of the Khwarazmshahs, and stayed in the city until the next summer, living in a former palace of Muhammad Khwarazmshah. The camp of Genghis Khan was located twenty days' journey from Samarqand. Therefore, Chang Chun preferred to stay in Samarqand and came to the camp when it was necessary before his final departure from Samarqand in December 1222. Li Zhichang provided a detailed description of Samarqand and depicted the customs and traditions of people who lived during this time. He pointed out that during the rule of the Khwaramzmshahs, Samarqand had a population of more than 100,00o families, which is equivalent roughly to a half million people:

方算端氏之未敗也, 城中常十萬餘戶。國破而來, 存者四之一, 其中 大率多回紇人, 田園不能自主, 須附漢人及契丹、河西等。其官亦以 諸色人爲之, 漢工匠雜處城中。有岡高十餘丈, 算端氏之新宮據焉, 太師先居之。185

When the dynasty of the Sunduan [Sultan] had not been yet defeated, the city [of Samarqand] usually had more than one hundred thousand families. But after the fall of the state only the fourth survived; among them in general, there are more people of Huihe, they cannot manage fields and gardens themselves and they depend on the Han people[Chinese], Qidan [Khitans], Hexi [Tanguts] and others. Their officials are also from diverse groups of people and Han craftsmen live together unsegregated in the city. There is a ridge of more than ten zhan high, the new palace of the Sunduan dynasty was built based on it.

183 Qiu Chang Chun Xi you ji; for the Russian and English translations, see Qiu Chang Chun Xi you ji, trans. Palladius 1866; Bretschneider, Notes on Chinese Mediaeval Travelers, 15-56; Qiu Chang Chun Xi you ji, trans. Waley 1931.

184 Qiu Chang Chun Xi you ji, 1: 12.

185 Ibid, 1: 14 . 
Li Zhichang also applied the term "Huihe" to refer to the country and people of the Khwarazmshahs, which can sometimes be translated as "Muslims."186 However, Huihe did not have this meaning during the Mongol conquest of Central Asia. Later the Mongols used the term in the form Huihui for Central Asians who were, in fact, mostly Muslims but it still did not circulate exclusively with the meaning "Muslims."

Samarqand was described as a former residence of the Khwarazmshahs by $\mathrm{Li}$ Zhichang. Yelü Chucai (119o-1244), the Minister of Genghis Khan, who participated in the conquest of Central Asia and visited most of the Khwarazmshah cities, also mentioned Samarqand as the capital of Muhammad Khwarazmshah. Gurganj was recorded as the residence of his mother. ${ }^{187}$

Detailed information about the Mongol conquest of Khwarazm is recorded in the official history of the Yuan dynasty compiled during the Ming period. This kind of information was also accurately recorded by Muslim authors. The Ming historians who compiled Yuan shi used the historical term Xiyu, meaning the Western Regions, in reference to Khwarazm. ${ }^{188}$ It means that Khwarazm was not viewed as waiguo "outside country," but a part of the Yuan Empire. Central Asians were grouped under the term Huihui, replacing the earlier form Huihe.

The Mongols in China divided people into four classes. The first class was the mengguren "Mongol people," a tiny but highly privileged minority. Next came the semuren "various people," persons with special status who mainly came from Central Asia, such as Turks and Persians. This class furnished higher officialdom. Like the Mongols, they were exempt from taxation and enjoyed preferential use of official services. This term was also applied to all westerners. The third group was called the hanren, "Chinese people," a term that generally means Chinese but was used to specify the inhabitants of northern China. This class included the Chinese and other Sinicized ethnic groups such as Jurchens, Khitans, and Koreans, who could be employed in some functions and who also formed military units under Mongol leadership. However, the Khitans, who formed the Western Liao dynasty in Central Asia, were probably classified as semuren rather than hanren. The last group was the nanren, "southern people," which referred to the former subjects of Song China. ${ }^{189}$

\footnotetext{
186 Emil Bretschneider, Notes on Chinese Mediaeval Travelers, ${ }_{15}{ }^{56}$.

187 Xi you lu, 25: 2a; also see Igor de Rachewiltz, “The Hsi-yu-lu 西遊錄 by Yeh-lü Ch'u-ts'ai 耶律楚材," Monumenta Serica 21 (1962): 1-128.

188 Yuan shi, 22: 116.

189 Frederick Mote, Imperial China 9oo-180o (Cambridge: Harvard University Press, 2003), 489-49o.
} 
Central Asians were classified as semuren. Yuan China had no specific terms to distinguish Turkic- and Persian-speaking populations. They were grouped under the name Huihui. The term Huihui had been used already in the histories of the Song and Liao dynasties. For instance, the Huihui Dashi tribe (Huihui Dashi $b u$ ) was given in the list of tribes that Yelü Dashi occupied on his road to the west. ${ }^{190}$ It is an interesting combination of terms. Both terms meant "Muslims" and were used during different periods in China. The word Huihui replaced Dashi during the Yuan period. Before the Mongols, Huihui was used as a version of Huihe. Therefore, it can be assumed that Huihui Dashi mentioned in Liao shi refers to Central Asia, specifically to the Khwarazmshahs and the Qarakhanids. The Huihui, meaning probably Uyghurs, also appeared in Song shi in the list of united armies of foreign polities that additionally to Huihui included the Tanguts, Jurchens and Tibetans. ${ }^{191}$ This term Huihui first mentioned in Mengxi bitan (Dream Pool Essays) written by Northern Song polymath and official Shen Kuo (1031-1095). The author referred to the Uyghurs from the Tang Anxi Protectorate. ${ }^{192}$ It proves that the term Huihui was indeed known and used for the Uyghurs before the Mongols and it was not an addition of the Mongol historians who compiled the histories of the Song and Liao.

It was during the Yuan dynasty that Huihui was applied mainly to people from the Western Regions. Probably in order to distinguish them from the Uyghurs, the Mongols adopted another term, Weiwu'er or Weiwu, which was simply a Mongol transcription of the word "Uyghur."193 It should be also noted that the term Huihui applied not only to Muslims but also to other peoples of different ethnic and cultural backgrounds, and according to Liu Yingsheng can be categorized into four groups: "Jewish Huihui" (Zhuhu Huihui), "Indian Huihui” (Jingduhei Huihui and Xindu Huihui), "Green Eyed Huihui” (Lüjing Huihui) and "Gypsy Huihui" (Luoli Huihui). ${ }^{194}$ The earlier term Huihe was also used in Chinese sources in the early Mongol period to refer to peoples of Central Asia and India regardless of their religion or origin. It confirms connections between Huihe and Huihui.

Hui is now the standard term for the Hui people, a group of Chinese-speaking Muslims living throughout modern China. They are considered to be the

\footnotetext{
190 Liao shi, 69: 1123.

191 Song shi, 449: 13235 .

192 Mengxibitan, 5: 225.

193 The modern Chinese transliteration Weiwu'er is derived from this term.

194 Liu, "A Lingua Franca along the Silk Road," 87-88; Liu Yingsheng 刘迎胜, Huayan yu fanyin:Zhonggu shidai houqi dongxi jiaoliu de yuyan qiaoliang 华言与蕃音: 中古时代后期 东西交流的语言桥梁 [Chinese and Foreign languages: Linguistic Connections of the East-West Relations during the late Middle Ages] (Shanghai: Shaghai guji, 2013), 119-120.
} 
descendants of Muslim travelers and traders from Central Asia and the Middle East who arrived in China along the Silk Roads in large numbers, especially from the Tang to the Yuan periods. During the Qing dynasty all Muslims living throughout the Empire, including the Turkic-speaking Muslim population such as modern Uyghurs, were also grouped under the term Hui, and the circulation of the term Uyghur was interrupted. However, the Turkic Muslim population did not use Hui as a self-designation.

The ancient term Uyghur was used first as the name of one of the Turkic ethnic groups and became a common self-designation during the Uyghur Khaganate from the seventh to the ninth centuries. Chinese sources transcribed the name as Huihe, while Muslim authors applied the term Toquzoguz, meaning "nine tribes." Therefore, the term Toquzoguz is sometimes viewed as related to the name Uyghur or even to the Chinese term jiu xing, meaning "nine families." In fact, both terms Uyghur and Toquzoguz appeared in Old Turkic inscriptions but were applied to different groups. The Chinese term jiu xing had different meanings and referred to various ethnic groups and its connection to the Uyghurs is disputed. ${ }^{195}$

After the Islamization of the Turkic peoples, ethnic group names began to be replaced by general designations such as "Muslims" or "Turki." The terms "Uyghur" and "Uyghuristan" continued to be in use among some groups in the region as self-designation probably until the sixteenth-seventeenth centuries; at least, these terms appeared in major sources of that period. Later the usage of the term disappeared, but people continued to believe in historical ties with the ancient Uyghurs, which was the most common and most preferred term, especially among local nineteenth-century intellectuals, as it was pointed out by prominent scholars of that time. ${ }^{196}$ Therefore, it was not unexpected that the term "Uyghur" was reintroduced by local representatives at the Conference (Qurultai) of Turkic intellectuals held in 1921 in Tashkent and most scholars agree that following the decision of this conference, it replaced the previous names. ${ }^{197}$

195 Vladimir V. Tishin, "K probleme sootnosheniia plemennykh nazvaniy uigur i tokuz oguz i ikh otnosheniia k "deviati familiiam" kitaiskikh istochnikov," Obschestvo i gosudarstvo $v$ Kitae (2014): 131-40.

196 For instance, see Vasily V. Bartold, "Dvenadtsat' lektsii po istorii turetskikh narodov Srednei Azii," in Sochineniia 5 (Moscow: Nauka, 1968), 192; Valikhanov, Chokan Ch. Sobranie sochineniy v piati tomakh (Alma-Ata: Glavnaia redaktsiia kazakhskoi sovetskoi entsiklopedii, 1985), vol. 3,158 .

197 It was the first meeting of an organization entitled "The Revolutionary Union of Altishahri-Jungharian Workers" that was organized to attract all people under Soviet rule who migrated from present-day Xinjiang. After the meeting, the organization was renamed "The Revolutionary Union of Uyghur-Altishahri-Jungarian Workers." For more 
It can be concluded that the first records of the term Huihui date back to the Northern Song dynasty. But it was used to describe the Uyghurs of the Tang period, which means that it was probably just a corrupt version of Huihe. The usage of Huihui with the meaning Muslims was started from the Yuan period and was probably first applied to the realm of the Khwarazmshahs.

\section{5 Conclusion}

Song-era Chinese sources recorded envoys from Northern India and the Islamic world that arrived in Kaifeng via the land routes in the late tenth and eleventh centuries. I attempted to utilize different hypotheses on the origin of these delegations and prove that these missions were dispatched by the Ghaznavid and Saljuq Sultans. There were also other missions from Muslim polities called Dashi and Miaoli that arrived in China accompanied by Qarakhanid envoys. The exact origin of these delegations can be discussed further but the role of the Qarakhanids in fostering international relations cannot be denied.

The Qarakhanids established themselves as middlemen between the TurkoIslamic and Sino-Tibetan worlds and helped their allies in the west to make contacts with Tibet and China. Thus, the Uyghur and Khitan delegations could cross the Qarakhanid territories and arrive to Ghazna. Diplomatic missions from Northern India, Asia Minor, and more remote territories of the Islamic world reached China accompanied by Qarakhanid envoys and official documents issued by the Khagans. These documents allowed the Qarakhanid allies not only to initiate diplomatic relations with the Song emperors but also to gain access to the Chinese market. The records on these missions give a clear idea of the trading networks and land roads in eleventh-century Central Eurasia.

The last section of this chapter reconsidering Chinese texts on the Khwarazmshahs demonstrates that Central Asia was known by the term "Uyghurs" in the twelfth and early thirteenth-century China. It proves the idea that accounts of the Uyghurs in Jin dynasty sources may also refer to the Qarakhanids and Central Asia in general.

details on the conference and its outcomes, see Pis'mo Razybakeeva Stalinu o rabote sredi uigur 11 November 1922, f.62, op.2, d.64, l.27-39. For conference participants, their nationality and occupation, see David Brophy, “Taranchis, Kashgharis, and the 'Uyghur Question' in Soviet Central Asia," Inner Asia 7, no. 2 (2005): 172-176; also see Sean R. Roberts, "Imagining Uyghurstan: Re-Evaluating the Birth of the Modern Uyghur Nation," Central Asian survey 28, 4 (2009): 361-81; Ablet Kamalov, "Birth of Uyghur National History in

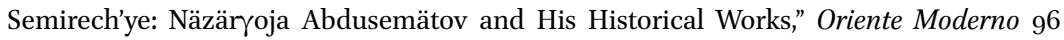
(2016): 182. 